\title{
Geophilosophical Realness of Risk: A Case Study In National Housing Authority Resettlement Sites In Albay, Philippines
}

Ana Marie Rico Abante ( $\sim$ anamarie.abante@bicol-u.edu.ph )

\section{Research}

Keywords: geophilosophy, hotspots, coldspots, hexagonal bin, risk quantity, risk realness

Posted Date: August 7th, 2020

DOI: https://doi.org/10.21203/rs.3.rs-52303/v1

License: (c) (1) This work is licensed under a Creative Commons Attribution 4.0 International License.

Read Full License

Version of Record: A version of this preprint was published at SN Applied Sciences on March 24th, 2021. See the published version at https://doi.org/10.1007/s42452-021-04442-6. 


\title{
GEOPHILOSOPHICAL REALNESS OF RISK: A Case Study in National Housing Authority Resettlement Sites in Albay, Philippines
}

\author{
Ana Marie R. Abante \\ anamarie.abante@bicol-u.edu.ph
}

\begin{abstract}
The Geophilosophical realness of risk, as introduced in this study constitutes risk hotspots or coldspots information that are stored and sorted in hexagonal bins which represent geographical space. Using the binning technique, the author disclosed the 29,400 hectares in Albay Philippines are 99\% significantly sited as risk hotspot physical space. Also, about 7,100 hectares, and 3,100 hectares have $95 \%$ and $90 \%$ significant risk hotspots, respectively. This study also presents resiliency being measured as a risk quantity, nearing a zero z-score that is enveloped by the fundamental geoinformation prerequisite to select safe, comfortable, and accessible space. The z-scores represent the risk hotspots and coldspots contained in hexagonal bins which mimic geographical aspects of the risk realness in Albay. The same z-scores were substituted for the 25 resettlement sites which provided answers to the query "what are the risk realities in NHA resettlement sites?" The results characterized the risk that are spreading at 14 resettlement's sites in Albay are generally located within risk hotspot areas. This information is significant in preventing and mitigating risk receptively and responsively. The researcher concludes that DRRM entails interdisciplinary thinking to apply geospatial data science to risk governance. This dissertation revealed that government intervention may be ineffective when people are steadily allowed to occupy risk hotspots that weakens their capacity to defy the quantified risk as well as the accumulated and unbearable risk residuals caused by the unforeseen effects of changing climate such as volcanic eruptions, lahar, increasing flooding, and pandemics. The Metatheorems in this study posit that dependable preparedness is unlikely if the risk hotspots and coldspots of geographical locations are unknown or unclear, which would guide environmental planners, engineers, development managers, and decision makers to direct the people to suitably select safe space, comfortable sites, and accessible sites. Furthermore, this study presents that scientifically informed policy is a must-risk-reduction solution to restore stability (state of balance). Therefore, the practical implication of this study is providing a basis where a decision maker can picture when stability is unattainable the approach is to bring the development in the tri-nodal cities outside the risk trending areas in Albay.
\end{abstract}

Keywords: geophilosophy, hotspots, coldspots, hexagonal bin, risk quantity, risk realness

\section{Introduction}

The Philippines is the third most disaster-prone country in the world according to the World Bank where there is low uptake of research and analytic thinking to inform local decision making on disaster risk management. Disaster risk reduction documentation started as early as 1814, after Mayon erupted disrupting people's lives and displacing them to look for lands suitable for planting crops far from this volcano but located near rivers and accessible to outside assistance.[1][3][4]. As multiple hazard events naturally re-emerge, the land morphology relatively implies physical and environmental modifications, making people vulnerable to environmental changes and discovered to be dangerous. [1][3][4] Evacuation-return behavior of farmers within a complete no-build-zone model (Mayon 6-Km Permanent Danger Zone of Albay), allowing barangay social and institutional facilities such as schools, barangay halls, and other developments turning into the new norm that contributed to the uncontrolled sprawl within the permanent and extended danger zones realization of the tri-nodal spatial developments now trending in Legazpi City, Tabaco City and Ligao City. [1][3][4] Undesired developments were analyzed using Open Street Map spatial data as well as the uncontrolled construction of buildings along the old railroads and rights-of-way, near rivers prone to flash floods carrying lahar deposits. [1][3][4]

This study sought to measure risk, residual risk, and extraneous errors, logical to the concept of assessing risk reality phenomenon. This study focuses on the significance of the implementation of Sendai Framework 2015-2030 to link to disasters happening within the $25 \mathrm{~km}$ radius referenced at the crater of Mayon Volcano to reduce human and economic losses by avoiding the creation of new risks in the built environment. This paper presents the conceptual framework of the study, applied from a Geophilosophical perspective, applying the semantics to stir up reasoning to quantify the risk reality, thus understanding risk reality conceptual space variables: multiple hazards, landscape vulnerability, passive exposure, preparedness, competency, and coping capacity. [1] [5][7][8] 
Fig.1, where $H$ symbolizes the combined scores of multiple hazards in Albay. The V symbolizes the combined scores for landscape vulnerability, which characterizes the condition of a piece of geographically enclosed land ajar to alteration (physical changes) brought by floods, bank erosion and other hydrological related hazards that may occur when river discharge exceeds its channel's volume, causing the river to overflow onto the downstream alluvial flats as well as the coastal area that convey different states of discomfort, security, worries, distress, angst, and more. Landscape vulnerability is a variable to quantify risk reality. [1][4][6][9][10] The E symbolizes the combined scores which measure the static position of dwelling structures, or tangible human assets that may be sited in hazard-prone areas likely to experience hazard events of different magnitudes. [1] [4][6][9][10] The preparedness, competency, and coping capacity variables carries the score that characterizes the overall capability of the local government in terms of income classification of LGUs approved by the Department of Finance to substitute the varying data associated with risk reduction and local growth.[1] [4][6][9][10] The preparedness (Cp) was linked with the spatial equality in terms of mitigation interventions, on the contrary one the landscape vulnerabilities are unmitigated, this variable is then linked with unsafe conceptual space. [1] [4][6][9][10] The competency $(\mathrm{Cm})$ was linked with the social injustice in terms of competency to live comfortably which characterizes the general population repetitively evacuated or relocated to avoid any fatal accidents at times their lives are affected by hazard events such as volcanic eruption, flooding and so on. Also, competency variable was linked with careful selection of comfortable conceptual space that plainly connecting the people to the place of work and social support facilities.[1] [4][6][9][10] The comfortable conceptual space is also linked with the social injustice in terms of spatial accessibility (road and/or tape drive access) characterizing the general demands of the elderly, youngsters, significant women, PWD, displaced, exposed and other deprived people. [1] [4][6][9][10] The coping capacity (Co) was linked with the receptive accessibility variable. It is also spatially linked with active exposure and preparedness at all levels of risk reduction management. [1][4][6][9][10]

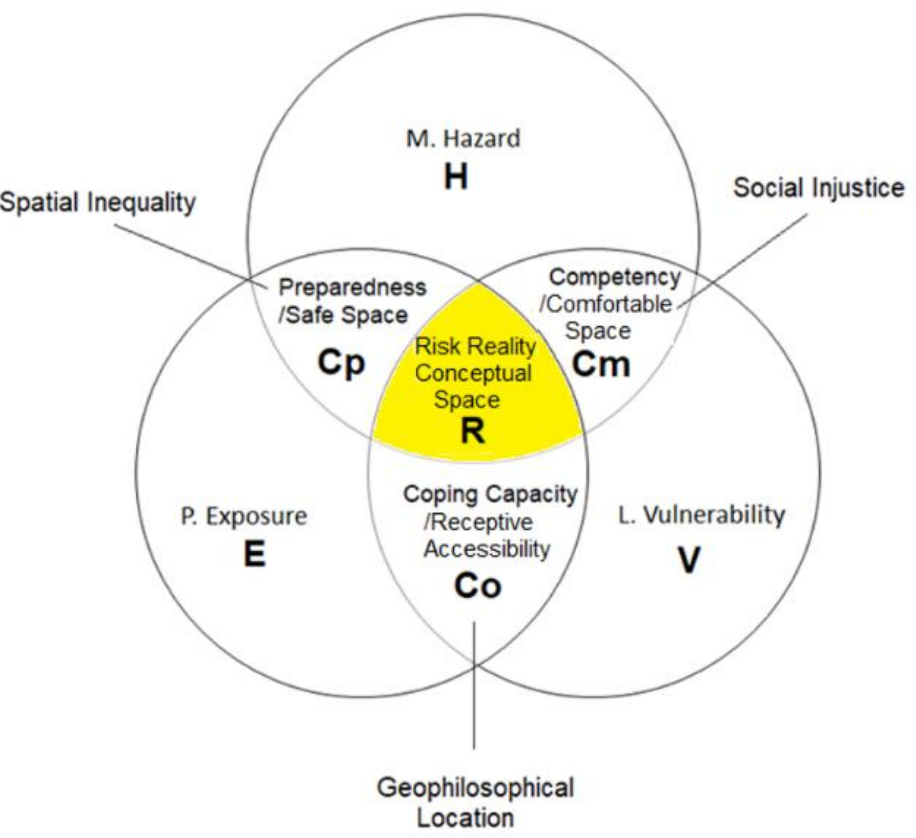

Fig.1 Risk Reality Conceptual Space (Abante, 2020)

The Y-junction of the Gärdenfors-inspired conceptual spaces are attributed to the three (3) paired variables that are logical where risk reality is expressed as Risk $\rightarrow$ function (Multiple Hazards, Landscape Vulnerability, Passive Exposure, Preparedness, Competency, Coping Capacity) where $\mathrm{H} \rightarrow$ multiple hazards; V $\rightarrow$ Landscape Vulnerability; $\mathrm{E} \rightarrow$ passive exposure; $\mathrm{Cp} \rightarrow$ preparedness (tied with safe conceptual space); $\mathrm{Cm} \rightarrow$ Competency (tied with comfortable space); and $\mathrm{Co} \rightarrow$ Coping capacity is tied with receptive accessibility). [1][4][6][9][10][31][32][33] [35][36][37][38][39][40][41][42][43] 


\section{Methods}

87

88

89

90

91

92

93

94

95

The study was designed to contextualize and examine the on risk hotspots and coldspots to quantify risk realities suffered by National Housing Authority (NHA) resettlement sites in Albay using GIS overlay and hexagonal binning technique to store and sort information to assess spatial patterns and quantify risk elements' statistical data to determine where the risk hotspot and coldspot are located using the ArcGIS's Getis-Ord Gi* Statistical and Moran's I Test. The researcher put together Metatheorems objects and parameters to requisite to perform the following: risk-enhanced resettlement site selection modeling; review the risk realness that is reliant to the computational risk reduction; and test the proposed site selection model parameters for settlement or resettlement sites as well as to examined the actuality of Geophilosophical realism of assessing the potential risk recurring in addition to the accumulated residual risk from past hazard events.

\subsection{Organizing Primary Spatial Data.}

Primary data were collected from OpenStreetMap and published spatial data by government line agencies. The input data were classified into ordinal scale having an ordering rating and organized to depict in a vector data formal language supported by the database built-in the GIS software used in characterizing risk elements' features it represents. In processing and quantifying the risk reality as well as selecting safe space, comfortable space, and accessible space or suitable sites for settlement/resettlements, binning techniques proved storing weighted values were achieved using the binning parameters as shown in Fig. 2.

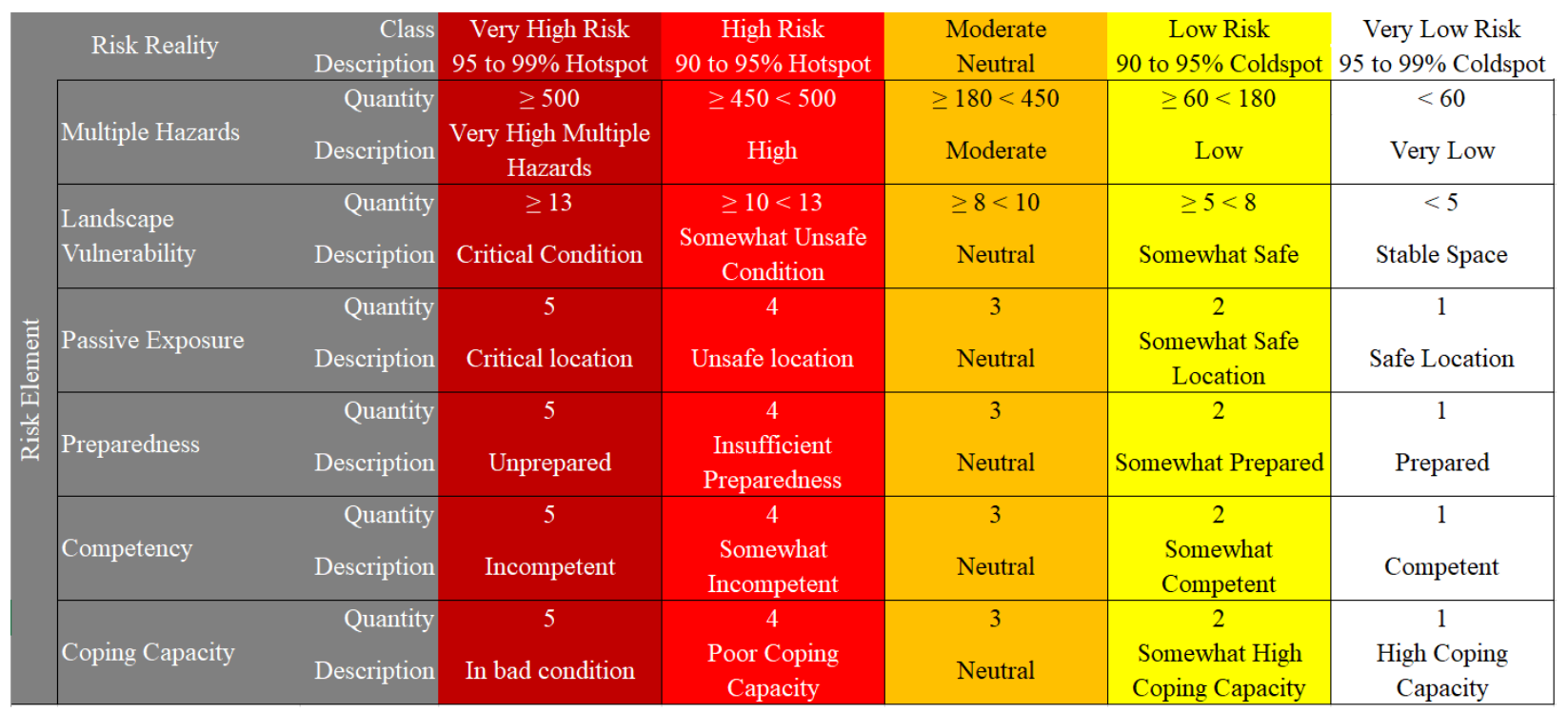

Fig. 2 Risk Reality Binning Parameters (Abante, 2020)

The multiple hazards aggregated scores are classified into five classes regarded as very high to extremely high, high, moderate, low and very low to absent. The landscape vulnerability aggregated scores are separated into five classes regarded as very high to extremely high, high, moderate, low and very low to absent. The passive exposure were classified into 5 classes, although in this case study the interpretation of critical locations are areas near or within $100 \mathrm{~m}$ reckoned from the OSM building footprints and/or OSM road centerlines to also picture where the development or sprawl are located. The preparedness, competency and coping capacity were classified into five classes regarded as very high to extremely high, high, moderate, low and very low to absent.

The risk reality was regarded as the location or bin where Hotpot is possible and likely. It was interpreted as the multiple hazards variables having to with any of the following: unstable slopes; critical elevations; regular flooded 
areas were given 100 weights, soil erosion prone areas which were based on soil characteristics, areas near riparian rivers were given 20 weights, foreshore extent altered by storm surge were given 20 weights, areas susceptible to geomorphological changes cause by Lahar, areas susceptible to Lava were given 100 weights. OSM Buildings and roads coincidence (passive exposure) which were given the highest score and were extracted by buffering the lines (OSM road) and polygons (OSM buildings) with 100 meters to represent nearness or density using Geoprocessing Mapping tools of ArcGIS. Preparedness, Competency and Coping Capacity were assumed comparable to the income classification of cities and municipalities in Albay to model risk hotspots, but this variable may partiality affect the risk hotspot analysis, on the other hand these variations also were assumed at the same level or equitable to 1 up to 5.

126

127

128

129

130

131

132

133

134

135

136

137

138

139

140

141

142

143

144

145

146

147

148

149

150

151

152

153

154

155

156

157

158

159

160

161

162

163

164

165

166

167

\subsection{Risk Reality Contextualization}

In this study, risk reality refers to the quantified risk state where the function (risk reality) multiple hazards, landscape vulnerability, passive exposure, preparedness, competency, and coping capacity. Risk Realness refers to the state of being at risk. The contextualization was necessary to portray the risk reality parameters that is geocentric and grounded golden ratio and golden triangle that disclosed the vertices of resiliency that were reckoned at the geometric center. The risk realness was regarded as a space promoting safety and protection. It also refers to the state of being at risk wherein the state of actuality or existing situation is objectively lucid in the physical environment where limits are contained in a hexagonal-shaped area whose segments are measured equidistant at 500 $\mathrm{m}$.

\subsubsection{Risk Reality Geometric center}

In this study, the conceptualization of the geometric center was grounded by the Fibonacci Golden Ratio and Schoen Golden Triangle. The geometric center is where the risk reality is at 0.008 units. It is regarded to be a resilient space or a Gärdenfors-inspired conceptual space when it conforms to the three criteria: safe, comfortable, and accessible space. Table 1 and Fig. 4 shows that the geometric center is positioned at plane coordinates $x 0, y 0$. It pertains to the vertex of the first isosceles triangle $\Delta 1 \rightarrow$ lowest risk reality quantityhighest risk reality quantity $\mathrm{H} \mathrm{x} \mathrm{V} \mathrm{x} \mathrm{ECp} \mathrm{c}$ Cm xCo $1 \times 1 \times 15 \times 5 \times 511250.008$ near zero risk reality quantity proving that the vertex of resiliency is significant when risk reality quantity is nearing zero.

\subsubsection{Risk Reality Phi}

The base line segment $\mathrm{AB}$, where the object theorem is written as line segment $\mathrm{AC} \rightarrow$ line segment $\mathrm{AB} \rightarrow$ 125 segment quantity units $\rightarrow$ also regarded as the Risk Location Quotient (RLQ) unit. When R > 125 risk quantity regarded as exceeds the upper limit in quantifying risk reality it is regarded that the computation result defies the golden ratio. It is interpreted as an end which leads to a new beginning moving from one sensitive phase to a more intense risk level because the risk reality $\rightarrow 125 \neq$ Fuzzy Risk Reality $>125$.

This study proved that the receptive-responsive-stability isosceles $\Delta \equiv$ unreceptive-unresponsive-socio-spatial

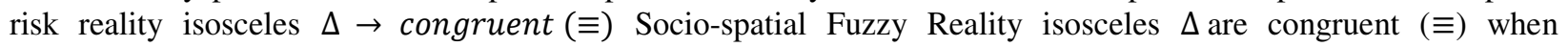
grounded by the Fibonacci Golden ratio and Schoen Golden triangle, where $\mathrm{C} \rightarrow$ Vertex of Resiliency $\rightarrow$ Angle kappa $\rightarrow 36^{\circ}$, and $\mathrm{AC} \rightarrow \mathrm{BC}$ are asymptotic quantity segments with angle Alpha $\rightarrow \alpha \rightarrow$ angle Beta $\rightarrow \beta \rightarrow 72^{\circ}$ and the $\varphi$ upper limit $\rightarrow 125$ and $\varphi$ lower limit $\rightarrow 1$ is regarded for risk reality $\rightarrow$ hotspot, thus when $\varphi>125$ it is regarded to represent the hotspot $\rightarrow$ Risk Fuzzy Reality and when $\varphi<1$ it is regarded to represent information on resiliency or risk coldspot.

By diagramming all the segments' complex numbers, vertices draw from asymptotic segments by similar triangle technique where angles: $36^{\circ}, 72^{\circ}, 108^{\circ}, 144^{\circ}, 180^{\circ}, 216^{\circ}, 252^{\circ}, 288^{\circ}, 304^{\circ}$ and $324^{\circ}$ were revealed by drawing the parallel (//) lines or perpendicular lines which started the diagramming in the geometric center where $\mathrm{R}$ $\rightarrow 0.008$ positioned at coordinates $x_{0}, y_{0}$. The Metatheoretic presentation of stability and/or asymptotic line segments of the series of Isosceles $\Delta s$ is regarded continuous connectivity of $\varphi$ when segments of the $\Delta s \rightarrow$ base of the $\Delta$ representing the stability segment quantity $\rightarrow$ asymptotic segments representing the receptiveness and/or 
responsiveness $\rightarrow 1 \rightarrow 1: 1$ ratio $\rightarrow$ when $125<\varphi \geq 1 \rightarrow$ it represent risk reality, thus when $\varphi>125$ is regarded as risk fuzzy reality.

Analyzing the stability $\rightarrow \varphi \rightarrow 1: 1$ ratio $\rightarrow$ regarded as receptiveness-responsiveness proportion $\rightarrow 1$ to the risk reality $\rightarrow \varphi \rightarrow \frac{125<\varphi \geq 1}{125<\varphi \geq 1}$ Ratio regarded as unreceptiveness-unresponsiveness proportion $\rightarrow$ risk reality $\rightarrow 125<\varphi$ $\geq 1$, the $\varphi$ result is regarded to a Metatheorem for Phi $\rightarrow$ $\varphi \rightarrow \frac{\text { Risk Hotspot }(\text { Upper Limit) }}{\text { Risk Fuzzy Reality }\left(125 / 2 \text { Cosine } 72^{\circ}\right)} \rightarrow \frac{\left.\text { Risk Hotspot (Upper Limit) }+ \text { Risk Fuzzy Reality (Risk Hotspot Upper Limit } / 2 \text { Cosine } 72^{\circ}\right)}{\text { Risk Hotspot (Upper Limit) }}$ $\rightarrow$

$$
\begin{aligned}
& \frac{\text { Risk Hotspot (Upper Limit) }}{\text { Risk Fuzzy Reality }\left(\frac{125}{2 \operatorname{Cosine} 72}\right)} \rightarrow \frac{\text { Risk Hotspot (Upper Limit) }+ \text { Risk Fuzzy Reality }\left(\text { Risk Hotspot Upper Limit } / 2 \text { Cosine } 72^{\circ}\right)}{\text { Risk Hotspot }(\text { Upper Limit) }} \\
& \quad \rightarrow \frac{125}{R\left(125 / 2 \operatorname{Cosine} 72^{\circ}\right)} \rightarrow \frac{125+R\left(125 / 2 \operatorname{Cosine} 72^{\circ}\right)}{125} \rightarrow \frac{2 \operatorname{Cosine} 72^{\circ}}{R} \rightarrow 1+\frac{125 R}{2 \operatorname{Cosine} 72^{\circ}} \rightarrow \operatorname{Phi} \varphi=R^{2}+\frac{2 \operatorname{Cosine} 72^{\circ} R}{A B}- \\
& \frac{\left(2 \operatorname{Cosine} 72^{\circ}\right)^{2}}{A B}
\end{aligned}
$$

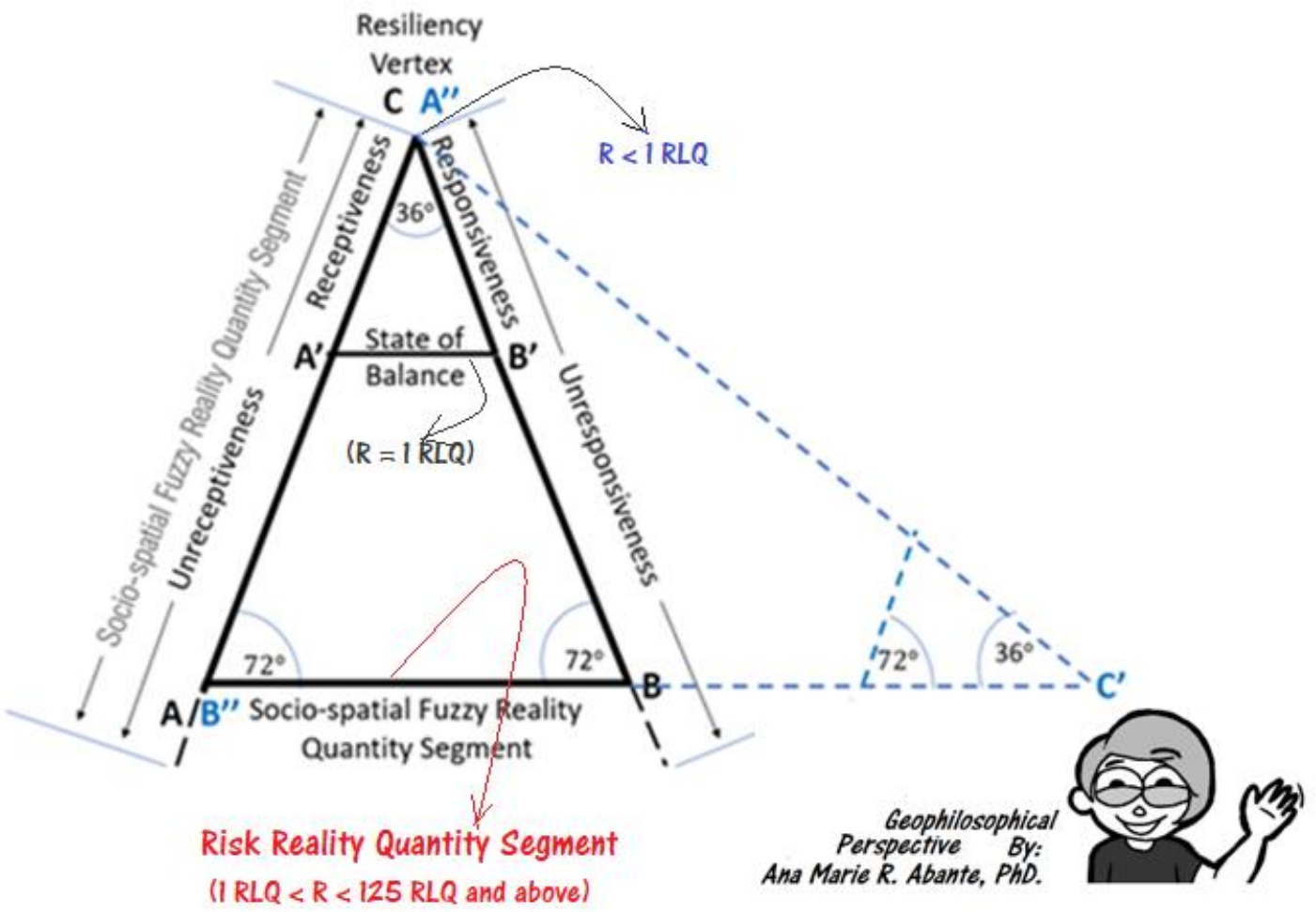

Fig. 3. Risk Reality Isosceles $\Delta$ Grounded by Schoen $\Delta$ (Abante, 2020)

The study proved that a spiral drawn after connecting the 25 vertices of resiliency of respective isosceles $\Delta s$ as shown in Table 1 when reckoned at the geometric center created a perfect circle when adding two more isosceles triangles. Table 1 proved that the geo center of risk reality is not at the centroid of a circle. The risk reality circle was a result of interconnecting the 27 arcs (spiral), then it continuous to loop once it formed the risk reality circle keeping the Risk Reality Phi, mathematically written as

$$
\text { Risk Reality Phi } \varphi \rightarrow R^{2}+\frac{2 \operatorname{Cosine} 72^{\circ} R}{A B}-\frac{\left(2 \operatorname{Cosine} 72^{\circ}\right)^{2}}{A B} \rightarrow R^{2}+0.00494427 R-0.00305572 .
$$

Fig. 4 revealed the relationships of the geometric center relative to the stability as shown in Fig, 3. This study bring to light when the risk reality is one unit it depicts stability. Table 1 divulged the risk reality lower and upper 
limits are consistent with the geometric center and spiral tail, respectively. The geometric center of the risk reality as shown in Fig. 4, and Fig. 6 are not located at the centroid of the risk reality circle that is grounded by Fibonacci Golden Ratio and Schoen Golden Triangle. The risk reality circle also revealed the asymptotic lines connecting the vertices segments 24 and 25 upward direction (following the flow from the geometric center, while the segments 25 and 26 downward direction where the flow also referred to the geometric center disclosing where the stability at segment 25 plunged to a length identical to stability segment 23.

Fig. 4 substantiate the risk reality quantity in terms of arc lengths. These arc lengths are keys to measure the prevention, mitigation, preparedness, response, and recovery quantity units (arc lengths) to obtain risk reality at one unit hinting a stability. The line of stability in this study refers to the fulcrum of the asymptotic quantity segments (Phi) depicting the Receptive-Responsive DRRM as shown in Fig. 6.
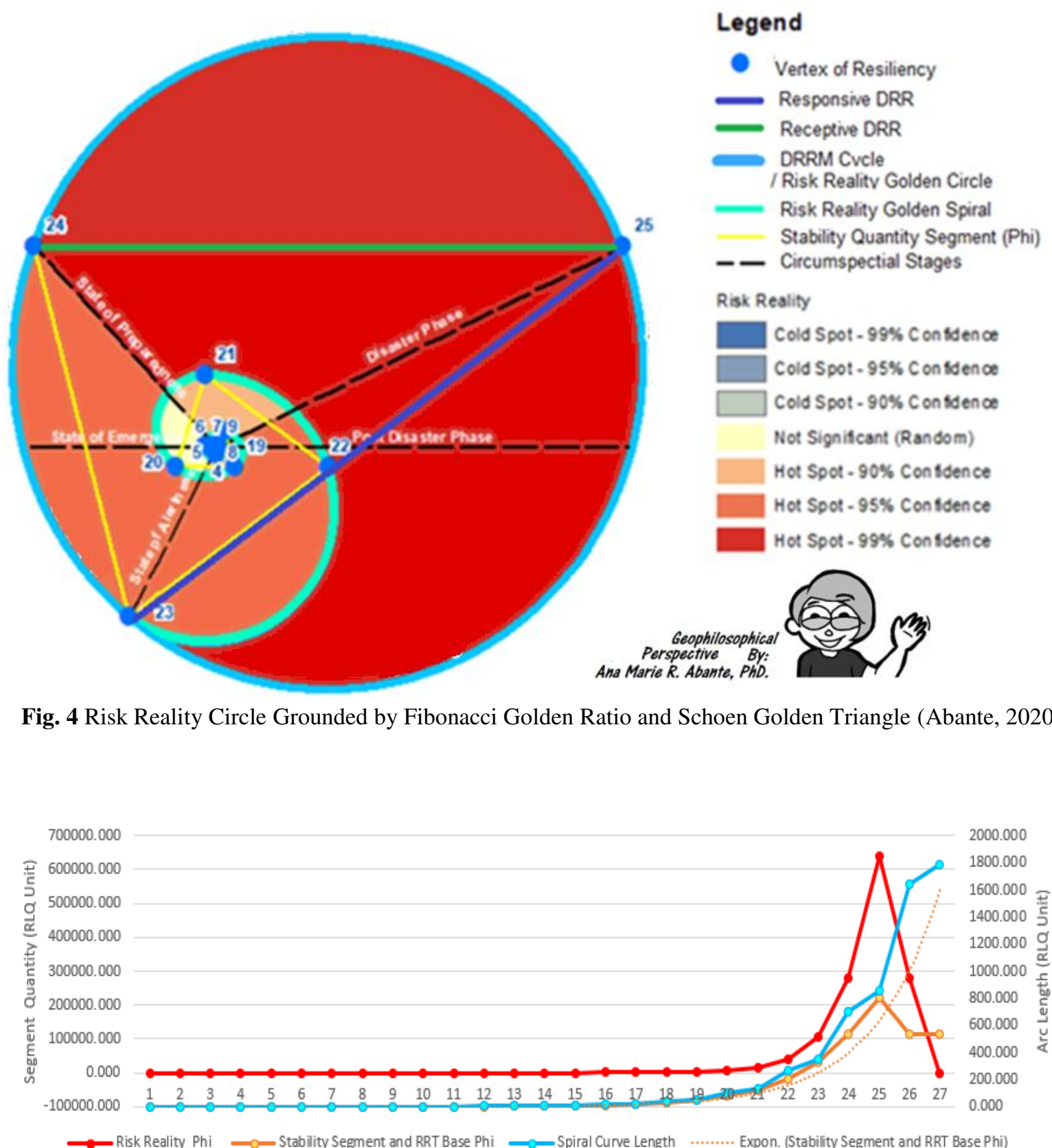

Fig. 5 Risk Reality Quantity Chart (Abante, 2020) 


\subsubsection{Vertices of Resiliency}

213 The vertex of resiliency refers to the point (geometry) where segment receptiveness and segment responsiveness are 214 measured at approaching Sine $18^{\circ}$ where Risk reality is equal to one, at an angle $36^{\circ}$ where the opposite segment is regarded as the state of balance line of the golden (isosceles) triangle as shown in Fig 3 and Fig. 5. The vertices of resiliency disclosed the relationships of the following: geometric center with risk reality equal to 0.008 unit positioned at 0.0 ; stability line with risk reality equal to one unit; risk reality upper limit with risk reality equal to 125 unit positioned at the end (spiral tail) shown in Table 1 and Fig. 4. The index table also revealed the 27 segments that are regarded as the baselines of the 25 isosceles triangles having $72^{\circ}$ asymptomatic angles and $36^{\circ}$ vertex angles. The spiral tail rests on the $23^{\text {rd }}$ vertex. It is where the last arc connects the $25^{\text {th }}$ vertex with $23^{\text {rd }}$ and $24^{\text {th }}$ vertices. The line segment connecting the $23^{\text {ti }}$ and $24^{\text {th }}$ vertices hinted at the longest stability line as illustrated in Fig. 3, Fig. 4, and Fog. 5.

223 Table 1. Vertices of Resilience Index Grounded by Grounded by Golden Ratio and Triangle. (Abante, 2020)

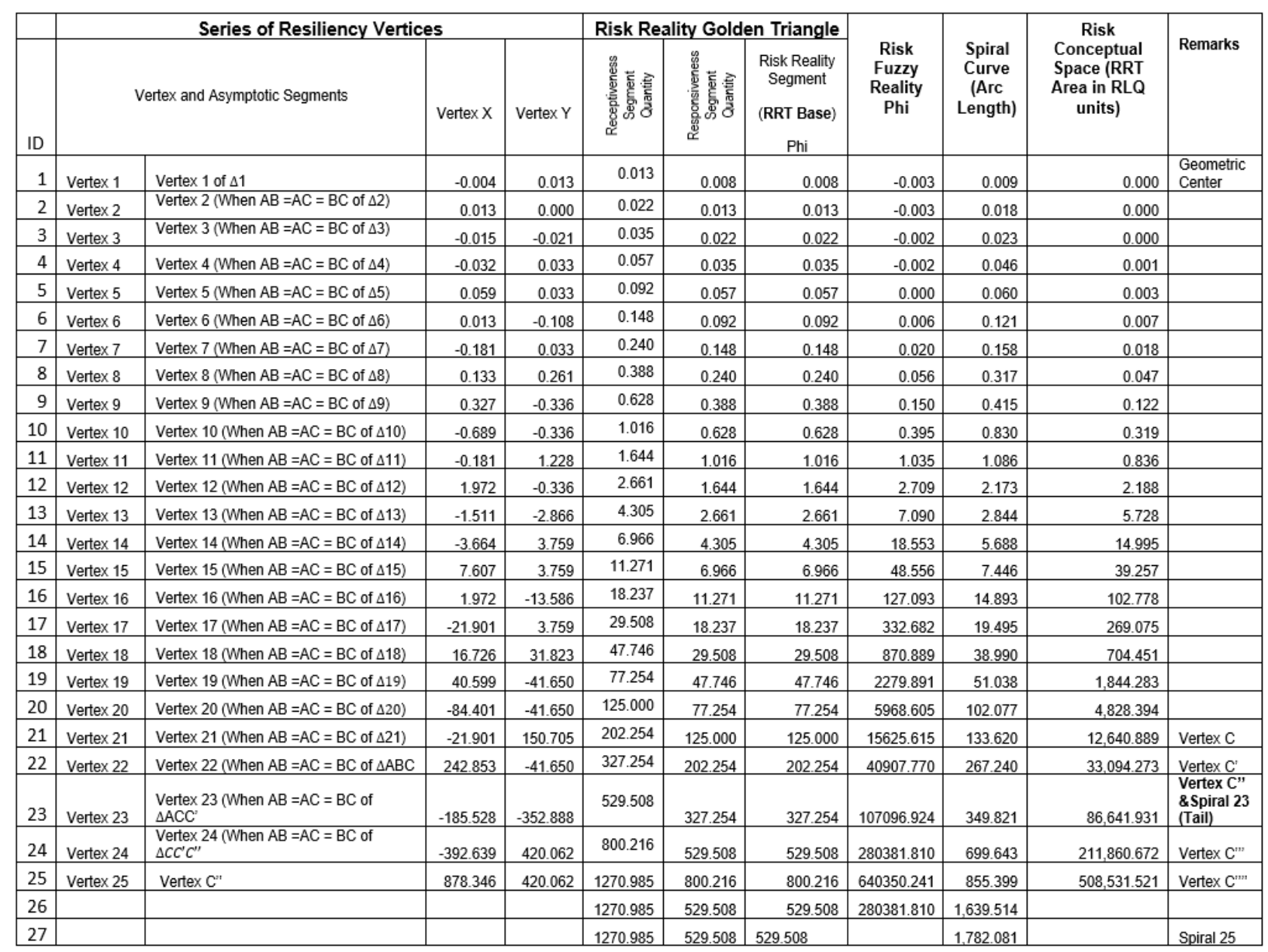

\subsubsection{DRRM-Circumspectial Isometric Stages Grounded by Risk Reality Phi}

The DRRM-Circumspectial Isometric Stages is presented to advocate the pairing of the five Circumspectial stages with the five DRRM cycles to measure risk reality through the geospatial information model that verbalizes that stability that is logical to site selection (space allocation). [1][4][5][6][9][10][11][12][32][33] While the DRRM cycle is itemized into prevention, mitigation, preparedness, response, and recovery, the circumspectial stages regarded as the state of alertness, state of emergency, state of preparedness, disaster phase and post-disaster phase. 
[1][6][9] The risk realness (geospatial) information give a rough idea of the complex interaction between a potential damaging physical event (regarded as multiple hazards in this study) combined with the vulnerability of NHA resettlement sites (where landscape critical condition and exposure (situation or nearness) are quantified and classified into hotspot, random or coldspot .[1][11][12]

Fig. 6 is grounded by Fig. 5 wherein the arc lengths are measurements of the DRRM cycle: prevention, mitigation, preparedness, response, and recovery. These five arc lengths concur with the five line-segments of the DRRM Circumspectial stages that are reckoned at the geometric center: State of Alertness; State of Emergency; State of Preparedness; Disaster Phase and Post Disaster Phase are reckoned at the geometric center of the risk reality circle. The Stability line-segment is measured from the end nodes of line-segments 'State of Alertness' (Vertex 23 in Fig. 4, Fig.5 and Table 1 as spiral tail) and 'State of Preparedness' (Vertex 24 in Fig. 4, Fig.5 and Table 1) measured from the geometric center. Preparedness is bounded by an arc line (risk reality partition) measured from Vertex 24 to Vertex 25 (as shown in Fig. 4, Fig. 5 and Table 1). Similarly, the line segment connecting Vertex 24 and Vertex 25 concur with the receptive risk reduction segment quantity (asymptotic segment (Phi as shown in Fig. 4) of the small Risk Reality Triangle (RRT) as shown in Fig. 3). Likewise, Vertex 25 and Vertex 23 concur with the responsive risk reduction segment quantity (asymptotic segment (Phi as shown in Fig. 4) of the small Risk Reality Triangle (RRT) as shown in Fig. 3). The Disaster Phase line segment in Fig.6 and Fig. 3 is measured from Vertex 25 to the geometric center. A horizontal line is drawn to create the partition of quick response and recovery. A line is drawn parallel to the Post Disaster Phase and measured from the geometric center is called the state of emergency. The researcher presents the State of Calamity can be drawn in between the State of Preparedness and Disaster Phase. The State of Calamity is seen as reliant on the State of Preparedness. Considering the preparedness remains a variable and perceived to be constantly changing, the five partitions relatively changes as hazard events intensifies and/or exposure continue to increase.

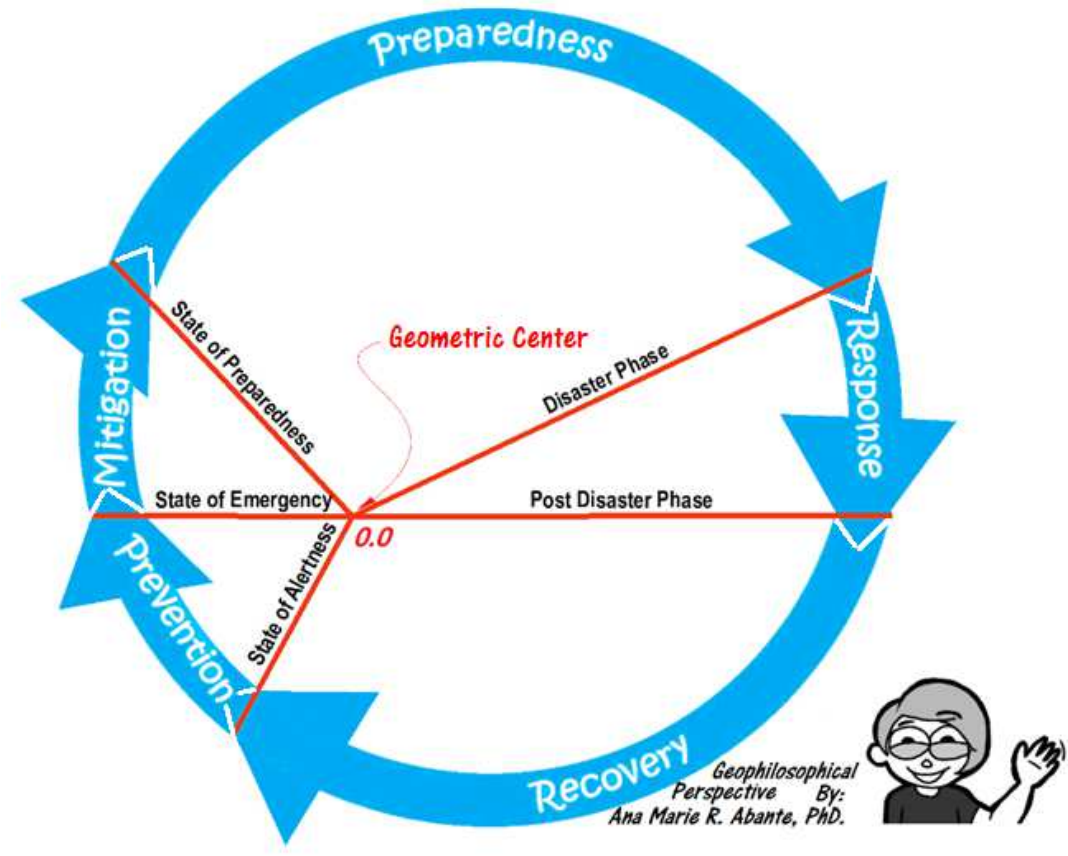

Fig. 6 DRRM-Circumspectial Isometric Stages Parameter (Abante, 2020)

\subsection{Risk-enhance Resettlement Site Selection Modeling}

The risk-enhance resettlement site selection modeling using geospatial information and ArcGIS software tested the following: Metatheorems object grounded by geophilosophical perspective on risk reality; Risk Reality Context Model Grounded by Golden Spiral; and Site Selection Modeling Grounded by Risk Reality Context Model. 
[1][26][27][28][29][30] The Binned Risk hotspot and coldspot was regarded to mimic the risk reality in Albay. [1][7][8][26][27] The geospatial information (Geoinformation) data model built up for this study revealed the nonexercise of the hexagonal binning technique leads to complexities in quantifying risk and evaluating the risk reality. [1][5][6][9][10][11][12][26][27][28][29][30] The binned statistical data were processed using the Gates Ord Gi* (geostatistical tool) to analyze the neighborhood of values for risk and its constituents. The Moran's index characterizes weight matrices significance for autocorrelation analysis. The z-scores were categorized into 7 levels of significance. The geospatial aspects and impact of data as illustrated and pinpoint the causes of specific geographic patterns that were reliant to the visual inspection and image interpretations were limited to the knowledge of the researcher's technical experiences as a photogrammetrist, cartographer, GIS specialist, geodetic and civil engineer and an environmental planner practicing land use planning) to interpret the risk variables and subvariants.

\subsubsection{Hexagonal Binning Technique.}

The risk hotspots and coldspot in Albay highlights the hexagonal binned data disclosing where the hotspots in terms of: multiple hazards binned geoinformation, landscape vulnerability binned geoinformation, passive exposure binned geoinformation, and capability (Preparedness, Competency and Coping Capacity) binned non-spatial data (attributes). [1][17][18] The data binning was reckoned $25 \mathrm{~km}$ from the crater of Mayon Volcano in Albay where the urban development trends (and sprawl) and constraints (risk hotspots) are located using hexagonal bin maps. Hexagonal bin map (tessellated cells created using ArcGIS 10.8 version) is fishnet-like or honeycomb-like hexagonal polygons arranged perfectly to store and sort the risk reality information distributed in the 25 resettlement sites in Albay. The 1,541 hexagonal bins which covers the $25 \mathrm{~km}$ radial distance measured from the crater of Mayon Volcano having an area of 154,160.14 hectares, plays an important role in analyzing the spatial variation of risk reality in Albay. Risk reality was measured in every $100 \mathrm{Ha}$ of land to depict the degree of confidence and rendering of risk hotspot and coldspot spatial patterns. Visualization of risk reality on the basis (real physical space) is doable using hexagonal bins with $100 \mathrm{Ha}$ area coverage, wherein an average person with a 0.50 -meter pace factor can walk a 500-meter radius (distance) or take 1,000 steps with 3-meter/second speed can measure the one-side of the hexagon in just 3-minutes or it takes 18 minutes to walk round a flat physical space regarded as a hexagonal bin. Fig. 7 demonstrates that the hexagonal bins (circularity of a hexagon grid) is a better way to represent data more naturally than square grids. The hexagon (bin) polygon (rather than a perfect circle) is a tessellated polygon regarded as a Hexagonal bin in this study.

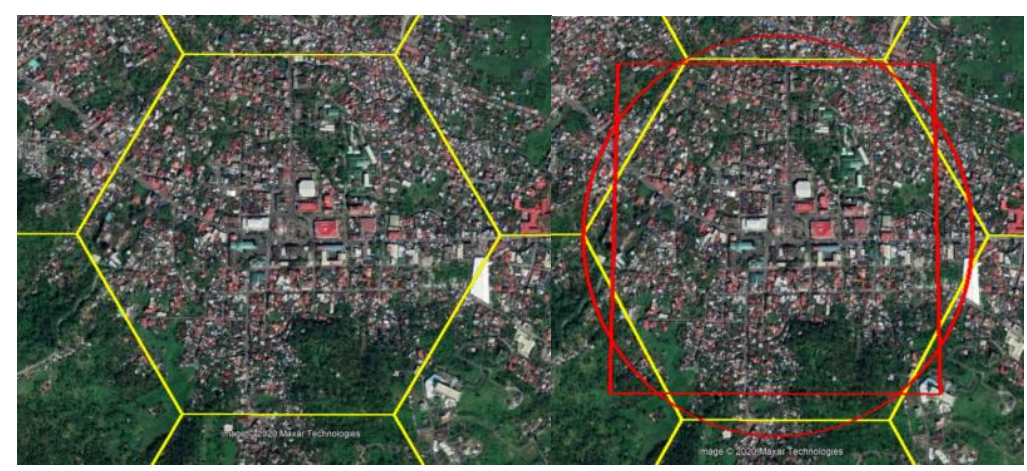

Fig. 7 Tessellated Hexagonal Bins (Polygons)

\subsubsection{Situational Analyses.}

The higher portion of the Mayon Volcano is a natural park (located within the permanent danger zone) reserved for the conservation of native plants and animals, their associated habitats and cultural diversity. At least a $24.4 \mathrm{~km}$ road network that leads access to the $8 \mathrm{~km}$ extended danger zone (remain an alienable and disposable and desirable for production forest uses. Without seeing the force of sprawl as people go forward to develop their lands and constructions of buildings near the gullies, alluvial fans at the foot slopes of the volcano, old railroads which were 
ruined by repetitive volcanic eruptions, people remain playing against disaster risk as multiple hazard events iteratively happen again and again.

The undesired buildings were built along rights-of-ways such as barangay/purok roads, farm-to-market roads, trails and tracks of trucks hauling the gravels and sands needed to develop cities and municipalities, dikes, evacuation routes, and so on. [1][3][4][31] The barangay (village) nodal centers or the location of the barangay halls is interconnected with road and road-like patterns. Density of buildings surrounding the barangay nodal centers varies depending on the slope, lift and other landscape features such as river and its bank erosion due to severe rainfalls. [1][4]

\subsubsection{Risk Areal Differentiation}

In this study this refers to the method to get the difference between two calculated risk quantities, wherein the negative residual value implies worsen risk reduction actions are applied to reduce risk; In contrast, the practical implication of positive residual affirms corrective risk reduction measures. [34] The geographic location (point features) of the 25 resettlement sites was overlaid with the hexagonal bins (polygon features) using ArcGIS's Geoprocessing Tool. The intersection of point and polygon features made possible transferring the hotspot, random and coldspot z-scores attributes from polygon to point map features. Then the areal differential technique was applied to get the residual risk $(\Delta R)$.

\subsection{Receptive and Responsive DRRM Review}

The Receptive-Responsive DRR Isometric Index as shown in Fig. 8 was created to simplify risk reduction parameters. It was tested and applied to review the relationship of the safe conceptual space reliance with the risk reality z-scores of the resettlement sites that may be safe, but not necessarily comfortable and accessible or may be comfortable temporarily (somewhat located far flung) but safe or resilient area. Metatheorems were used to further review the risk reality z-scores.[1] Notice the line formed by the cell with numerical value equal to one. It act as a partition when risk reality is less than or greater than one unit. 


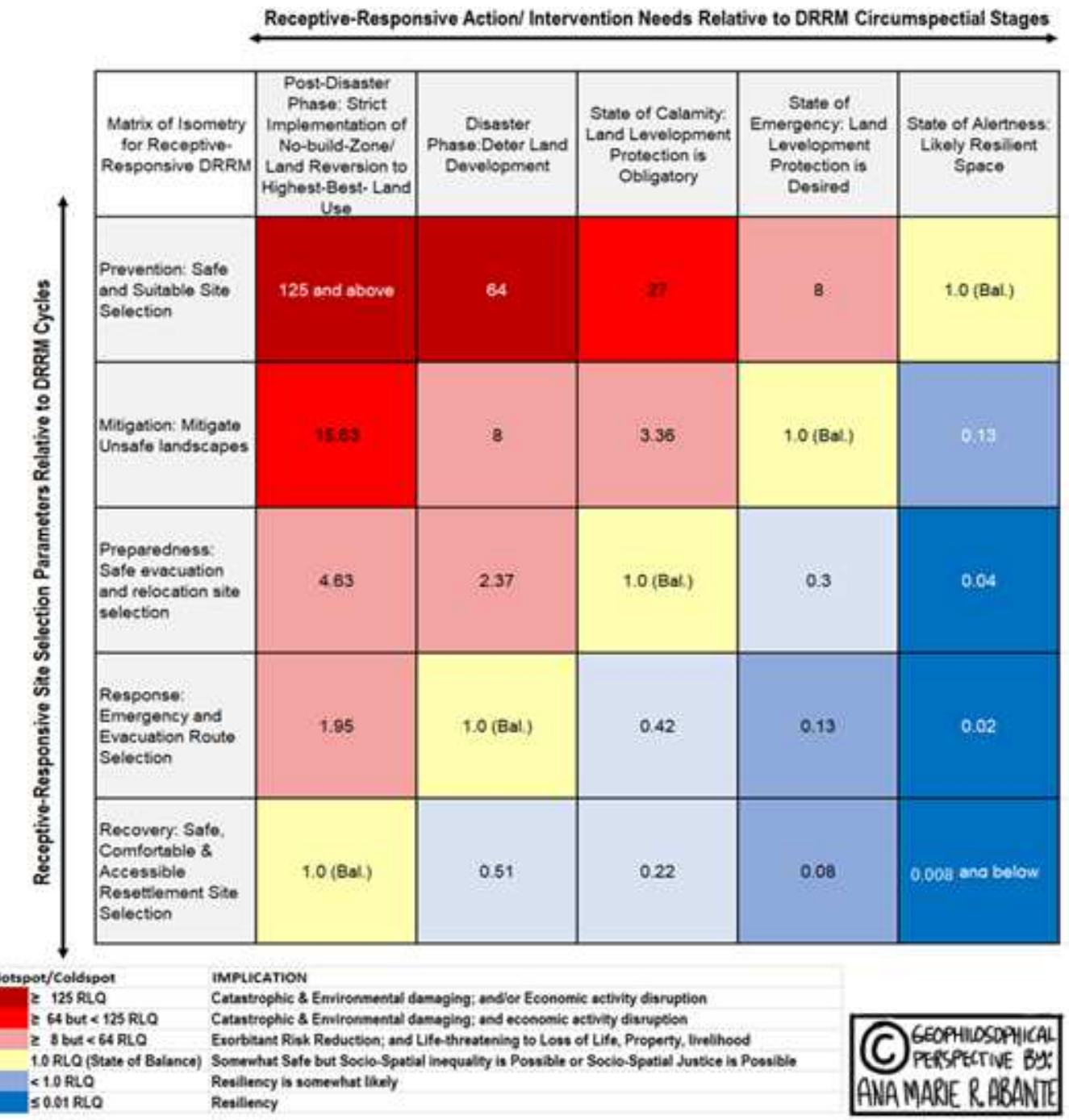

Fig. 8 Receptive-Responsive DRR Isometric Index (Abante, 2020)

\section{$3 \quad$ Results}

The risk reality and trend in terms of spatial information on multiple hazards, landscape vulnerability, passive, exposure and the nonspatial information on capability are regarded as the combination of the preparedness, competency, and coping capacity of the government. The hotspot incidence in terms of 623 bins or $62,300 \mathrm{Ha}$ regarded as the combined building and road incidences. Of all the risk elements this information is the independent variable of risk reality. Risk cannot exist in bins when passive exposure is nil. See the bin map at the end of the discussion. Unlike the first three (3) risk elements, the Capability is expressed as non-spatial information representing the attributions regarded as the other three (3) elements of risk, these are: preparedness, competency, and coping capacity. These elements characterize the denominator, taking the part (pairing) in cutting the multiple hazards, landscape vulnerability and exposure, the pairing are as follows: multiple hazards and preparedness, landscape and competency, and exposure and managing capacity. These pairing constitute the three (3) conceptual spaces supported by Metatheorems, these are: a safe conceptual space indicating there is spatial equality, comfortable conceptual space to stand for social justice, and philosophical location (conceptual space). Since the passive exposure is involved as an independent variable when paired with coping capacity hinted at the 
geophilosophical location as a conceptual space is the most important information that connotes land utilization and zoning.

The risk realities findings in the 25 resettlement sample sites in terms of: risk reality z-score processing result, risk reality overlay analysis result, risk realities tabulation, and visualization of risk realities in NHA resettlement sites. [1][19][20][21][22][23][24][25] The risk realities suffered by the NHA resettlement sites in Albay in terms of charting: risk reality, descriptive style, and conceptual space tabulation, risk reality suffered by NHA resettlement sites. [1][5]

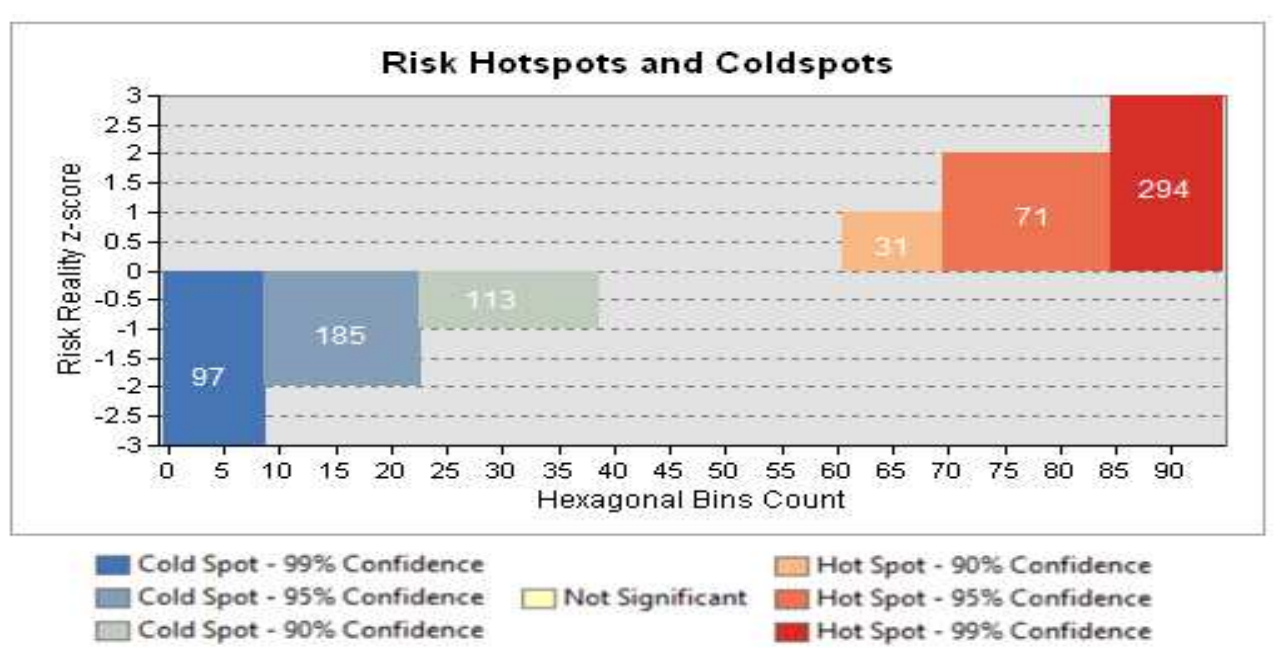

Fig.9 Risk Hotspots and Coldspots Bin Count

The more people utilize danger zones the more financial content is required to stay balanced following a zerocasualty strategy of Albay. Therefore, the bin maps for preparedness, competency and coping capacity were inputted with the income class of the urban centers and municipalities. It means each hexagonal bin is attributed to income class weighted from 1 (lowest) to 5 higher, indicating the 5\% budget allocation for DRRM programs and activities. See the bin maps at the end of the discussion on risk hotspots and coldspots in Albay. This graph below disclosed the sum of risk hotspots, random/insignificant or coldspots information that connects the risk reality z-scores: 294 hexagonal bins or 29,400 hectares of land are labelled as $99 \%$, significantly hotspot, 71 hexagonal bins are labelled 95\%, significantly hotspot, 31 hexagonal bins are 90\%, significantly hotspot, 113 hexagonal bins are 90\% significantly coldspot, 185 hexagonal bins are 95\% significantly coldspot and 97 hexagonal bins are 99\% significantly coldspot. The ArcGIS's Getis-Ord Gi* Statistical and Moran's I Test results also disclosed the general hotspot wherein the areas with z-scores varying from 1.65 to 1.96 cover the resettlement sites disclosed the following: Legazpi City, Ligao City, Tabaco City, Bacacay, Camalig, Daraga, Guinobatan, Libon, Malilipot, Malinao, Oas, Polangui, Sto. Domingo and Tiwi. On the contrary, the coldspots are generally depicted by z-score between $<1$ and $\mathrm{z}$-score $\leq 2.58$ which cover the following watershed divides: Balobo (Ligao-Guinobatan area), Banwang Gurang (Camalig-Jovellar area), Ogod (Camalig-Jovellar area), Polangui (Polangui-Oas area), Quinali 'A' (Camalig, Guinobatan, Ligao, Oas and Polangui area), Quinali 'B' (Malinao-Tabaco), Taque and Tiwi-Sangay area. Other fields are barely random values.

The risk realities suffered by resettlement sites are regarded as the lack of spatial quality regarded as receptiveness is unlikely (U) and short of social injustice regarded as responsiveness is unlikely (U) where stability is reliant on the segment quantity of unreceptiveness and unresponsiveness. The $\mathrm{N}$ indicates no certain suffering based on the scientific data findings, although some recipients of housing projects may disagree with this geospatial information modeling results. The following research output reveals the risk realities suffered by resettlement sites in terms of the following: risk reality, descriptive trend, conceptual space tabulation, and risk reality suffered by NHA resettlement sites. Table 2 exhibit the risk realities suffered by the resettlement site in Albay: Likely (Li), Somewhat Likely (SLi) and Unlikely (U); Social Justice: Likely (Li), Somewhat Likely (SLi) and Unlikely (U); 
Receptiveness: Likely (Li), Somewhat Likely (SLi) and Unlikely (U); Responsiveness: Likely (Li), Somewhat Likely (SLi) and Unlikely (U); and Stability: Likely (Li), Somewhat Likely (SLi) and Unlikely (U). [1] It also demonstrates where stability is unlikely regarded as suffering risks by resettlement sites. Based on scientific findings, the following suffered risk: Cullat (Daraga), Lamba (Legazpi), Ligao City, Miisi (Daraga), Oson (Tabaco City), Pinabobong (Tabaco City), Quitago (Guinobatan), Salvacion (Tabaco City), San Vicente (Tabaco), Sto. Domingo, Tabaco Housing Project, Tagaytay (Camlig), Taysan (Legazpi City).

Table 2. Risk Realities Suffered by NHA Resettlements in Albay (Abante, 2020)

\begin{tabular}{|c|c|c|c|c|c|c|c|c|c|c|}
\hline \multirow[b]{2}{*}{ ID } & \multirow[b]{2}{*}{ NHA Resettlement Site } & \multicolumn{3}{|c|}{ Present Risk Reality } & \multicolumn{3}{|c|}{ Risk Trend } & \multirow[b]{2}{*}{ 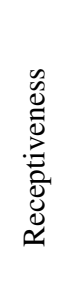 } & \multirow{2}{*}{ 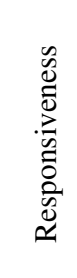 } & \multirow[b]{2}{*}{ 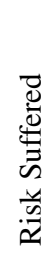 } \\
\hline & & 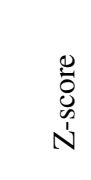 & 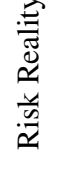 & 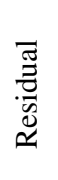 & $\ddot{\bar{a}}$ & $\begin{array}{l}\overline{\tilde{E}} \\
\stackrel{\tilde{Z}}{\Xi} \\
\cdot \vec{\Xi} \\
\end{array}$ & $\underset{E}{\stackrel{D}{D}}$ & & & \\
\hline 1 & Amore Resettlement Project & -1.38 & $\mathrm{C}$ & $\mathrm{N}$ & N.A. & $\mathrm{N}$ & $\mathrm{C}$ & $\mathrm{Li}$ & $\mathrm{Li}$ & $\mathrm{N}$ \\
\hline 2 & Banquerohan Resettlement Project Ph I & -0.66 & $\mathrm{C}$ & $\mathrm{N}$ & N.A. & $\mathrm{N}$ & $\mathrm{C}$ & $\mathrm{Li}$ & $\mathrm{Li}$ & $\mathrm{N}$ \\
\hline 3 & Banquerohan Resettlement Project Ph II & -1.31 & $\mathrm{C}$ & $\mathrm{N}$ & N.A. & $\mathrm{N}$ & $\mathrm{C}$ & $\mathrm{Li}$ & $\mathrm{Li}$ & $\mathrm{N}$ \\
\hline 4 & Bascaran Resettlement Project & -0.43 & $\mathrm{C}$ & $\mathrm{N}$ & N.A. & $\mathrm{N}$ & $\mathrm{C}$ & $\mathrm{Li}$ & $\mathrm{Li}$ & $\mathrm{N}$ \\
\hline 5 & Camalig Resettlement Project & -0.49 & $\mathrm{C}$ & $\mathrm{N}$ & N.A. & $\mathrm{N}$ & $\mathrm{C}$ & $\mathrm{Li}$ & $\mathrm{Li}$ & $\mathrm{N}$ \\
\hline 6 & Cullat Resettlement Project & 3.32 & $\mathrm{H}$ & $\mathrm{Y}$ & 11.02 & $\mathrm{Y}$ & $\mathrm{F}$ & $\mathrm{U}$ & $\mathrm{U}$ & $\mathrm{Y}$ \\
\hline 7 & Daraga Resettlement Project Ph I & -0.81 & $\mathrm{C}$ & $\mathrm{N}$ & N.A. & $\mathrm{N}$ & $\mathrm{C}$ & $\mathrm{Li}$ & $\mathrm{Li}$ & $\mathrm{N}$ \\
\hline 8 & Daraga Resettlement Project Ph I & -0.82 & $\mathrm{C}$ & $\mathrm{N}$ & N.A. & $\mathrm{N}$ & $\mathrm{C}$ & $\mathrm{Li}$ & $\mathrm{Li}$ & $\mathrm{N}$ \\
\hline 9 & Daraga Resettlement Project Ph II & -0.40 & $\mathrm{C}$ & $\mathrm{N}$ & N.A. & $\mathrm{N}$ & $\mathrm{C}$ & $\mathrm{Li}$ & $\mathrm{Li}$ & $\mathrm{N}$ \\
\hline 10 & Lamba Resettlement Project & 0.61 & $\mathrm{H}$ & $\mathrm{Y}$ & 0.37 & $\mathrm{Y}$ & $\mathrm{H}$ & $\mathrm{U}$ & SLi & $\mathrm{Y}$ \\
\hline 11 & Ligao Resettlement Project & 2.26 & $\mathrm{H}$ & $\mathrm{Y}$ & 5.12 & $\mathrm{~N}$ & $\mathrm{~F}$ & $\mathrm{U}$ & SLi & $\mathrm{Y}$ \\
\hline 12 & Mauraro Resettlement Project Ph II & -0.55 & $\mathrm{C}$ & $\mathrm{N}$ & N.A. & $\mathrm{N}$ & $\mathrm{C}$ & $\mathrm{Li}$ & $\mathrm{Li}$ & $\mathrm{N}$ \\
\hline 13 & Miisi Resettlement Project & 4.19 & $\mathrm{H}$ & $\mathrm{Y}$ & 17.53 & $\mathrm{~N}$ & $\mathrm{~F}$ & $\mathrm{U}$ & $\mathrm{U}$ & $\mathrm{Y}$ \\
\hline 14 & Oas Resettlement Project & -0.32 & $\mathrm{C}$ & $\mathrm{N}$ & N.A. & $\mathrm{N}$ & $\mathrm{C}$ & $\mathrm{Li}$ & $\mathrm{Li}$ & $\mathrm{N}$ \\
\hline 15 & Oson Resettlement Project & 4.54 & $\mathrm{H}$ & $\mathrm{Y}$ & 20.61 & $\mathrm{Y}$ & $\mathrm{F}$ & $\mathrm{U}$ & $\mathrm{U}$ & Y \\
\hline 16 & Pinabobong Resettlement Project & 3.40 & $\mathrm{H}$ & $\mathrm{Y}$ & 11.57 & $\mathrm{~N}$ & $\mathrm{~F}$ & $\mathrm{U}$ & $\mathrm{U}$ & $\mathrm{Y}$ \\
\hline 17 & Polangui Resettlement Project & -1.62 & $\mathrm{C}$ & $\mathrm{N}$ & N.A. & $\mathrm{N}$ & $\mathrm{C}$ & $\mathrm{Li}$ & $\mathrm{Li}$ & $\mathrm{N}$ \\
\hline 18 & Quitago Resettlement Project & 1.08 & $\mathrm{H}$ & $\mathrm{Y}$ & 1.18 & $\mathrm{~N}$ & $\mathrm{C}$ & $\mathrm{U}$ & SLi & $\mathrm{Y}$ \\
\hline 19 & Salvacion Resettlement Project & 2.54 & $\mathrm{H}$ & $\mathrm{Y}$ & 6.44 & $\mathrm{Y}$ & $\mathrm{F}$ & $\mathrm{U}$ & SLi & $\mathrm{Y}$ \\
\hline 20 & San Vicente Resettlement Project & 0.69 & $\mathrm{H}$ & $\mathrm{Y}$ & 0.48 & $\mathrm{Y}$ & $\mathrm{H}$ & $\mathrm{U}$ & SLi & $\mathrm{Y}$ \\
\hline 21 & Sto. Domingo Resettlement Project Ph I & 0.86 & $\mathrm{H}$ & $\mathrm{Y}$ & 0.74 & $\mathrm{Y}$ & $\mathrm{H}$ & $\mathrm{U}$ & SLi & $\mathrm{Y}$ \\
\hline 22 & Tabaco Housing Project & 0.69 & $\mathrm{H}$ & $\mathrm{Y}$ & 0.48 & $\mathrm{Y}$ & $\mathrm{H}$ & $\mathrm{U}$ & SLi & $\mathrm{Y}$ \\
\hline 23 & Tagaytay Resettlement Project & 1.97 & $\mathrm{H}$ & $\mathrm{Y}$ & 3.89 & $\mathrm{Y}$ & $\mathrm{H}$ & $\mathrm{U}$ & SLi & $\mathrm{Y}$ \\
\hline 24 & Taysan Resettlement Project & -0.07 & $\mathrm{Ra}$ & $\mathrm{Y}$ & N.A. & $\mathrm{N}$ & $\mathrm{Ra}$ & $\mathrm{U}$ & $\mathrm{Li}$ & $\mathrm{Y}$ \\
\hline 25 & Taysan Resettlement Project & 1.84 & $\mathrm{H}$ & $\mathrm{Y}$ & 3.40 & $\mathrm{Y}$ & $\mathrm{H}$ & $\mathrm{U}$ & SLi & $\mathrm{Y}$ \\
\hline
\end{tabular}

Note: $C \rightarrow$ Coldspot; $H \rightarrow$ Hotspot; Ra $\rightarrow$ Random; $F \rightarrow$ Fuzzy Reality; $Y \rightarrow Y e s ; N \rightarrow$ No; VH $\rightarrow$ Very High; H $\rightarrow$ High; $M \rightarrow$ Moderate; L $\rightarrow$ Low;

\section{Discussion}

The Risk Reality in Albay in terms of the spatial aspects of the three risk elements such as multiple hazards, landscape vulnerability and passive exposure, locate the risk hotspots or coldspots in the study area. The multiple hazards hotspots with 99\% level of confidence are located within the Mayon $6 \mathrm{~km}$ permanent danger zone; between the 6 to $8 \mathrm{Km}$ extended Mayon danger zone covering Tabaco City and Malilipot. It also includes areas near the Albay Lineament fault line crossing the town of Libon, Oas, Ligao City, Guinobatan, Camalig, Daraga, ending in Legazpi City. In terms of the landscape vulnerability, hotspots with $99 \%$ level of confidence greatly cover the $4 \mathrm{Km}$ buffer area reckoned from the $6 \mathrm{~km}$ permanent danger zone. Measuring Passive Exposure relies on the location of building and road network where the said multiple hazards and passive vulnerable hotspot areas exist. The technique 
on binning information on hexagonal cells reveals that about 29,400 hectares in Albay are significant risk hotspots, with $99 \%$ confidence. Also, at least 7,100 hectares of land are significant risk hotspots, with $95 \%$ confidence, and 3,100 hectares are significant risk hotspots with $90 \%$ confidence. The risk hotspot areas reach up to 15 kilometers from the Mayon Volcano's crater, covering Legazpi City, Daraga, Camalig, Guinobatan, the eastern section of Ligao City, Tabaco City, Malilipot, the western portion of Bacacay and Sto. Domingo. In terms of Coldspots or areas measured to be resilient: within the $25 \mathrm{~km}$ radius study area measured from the Mayon's crater, the mountainous portion of Mount Malinao (covering Malinao and Tiwi), Mount Masaraga (covering western portion of Tabaco City, eastern portion of Polangui and Ligao City), mountain hill ranges of the watershed and production forest (covering Libon, Oas, southern portion of Ligao City, Guinobatan and Camalig) and Jovellar) are measured as coldspots, with $90 \%$ level of confidence.

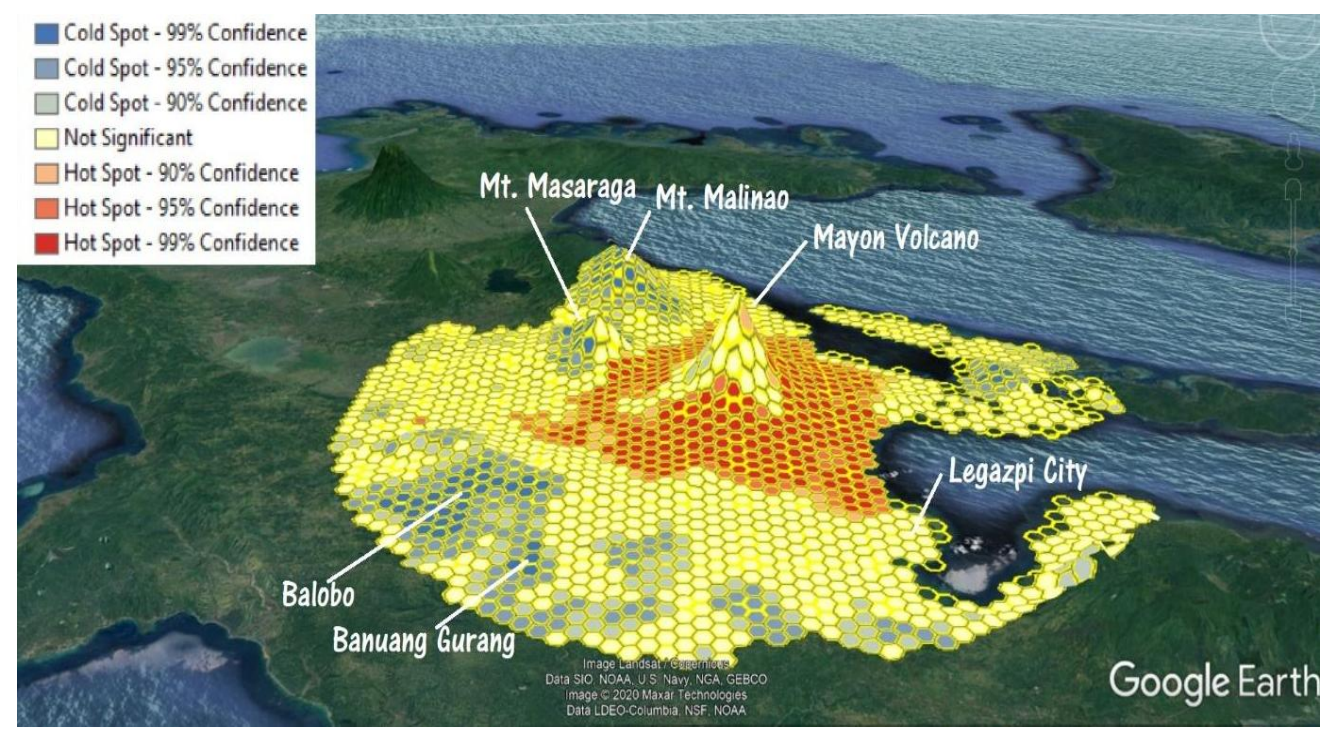

Fig. 10 Risk Hotspot and Coldspot Tessellated Bins Visualization in Google Earth Platform

Although these hotspots and coldspots outline the risks in spatial aspects relative to quantifying spatial equality, the term social justice remains reliant to the nonspatial aspects of capability. [1][35][36][47][38][39][40] These nonspatial aspects include preparedness, competency and coping capacity of the LGUs, where preparedness, competency and competency ratings were based on income class, and the 5\% mandatory fund for prevention, mitigation, preparedness, response and recovery. [1]The variations which influence risk reality to either boost local development (if risk is reduced to bearable quantity), or to a worsened state if risk realities continue accruing. [1] A worsened risk reality implies that the socio-spatial reality in terms of spatial equality, social justice accessibility and stability are unmet. [1]

Socio-spatial reality, in terms of spatial equality, social justice accessibility and stability in the NHA resettlement sites in Albay were examined. This revealed the existence of a spreading risk in the following resettlement sites: Miisi and Cullat in Daraga ; Pinabobong, Tabaco Housing, Salvacion and Oson in Tabaco City, Taysan Phase I and II, and Lamba in Legazpi City; Ligao City; Quitago in Guinobatan; Sto. Domingo and Tagaytay in Camalig. A total of thirteen (13) out of twenty-five (25) resettlement sites in Albay are located within risk hotspot areas. Spatial equality (safe conceptual space) is unlikely (unsafe space) in all the above-mentioned resettlement sites except Taysan I in Legazpi City. In terms of Social Justice (comfortable conceptual space) are unlikely (unsafe space) in Cullat, Miisi, Oson, and Pinabobong, and the rest of the sample sites are found to be slightly likely comfortable sites. In terms of the accessibility of resettlement sites, Oson, Pinabobong and Quitago are unlikely accessible (not easily accessible), but Lamba, Miisi, Tagaytay, Taysan Phase I and II and Sto. Domingo seems slightly likely to be accessible. The nearness of Cullat, Ligao, Salvacion, San Vicente and Tabaco Housing to the social facilities mostly located in the tri-nodal cities of Albay (Legazpi, Ligao, Tabaco) place these resettlement sites likely accessible. But because these 13 resettlement sites are consequently located in risk hotspot areas, by applying the Metatheorems of this study, stability for these sites is unlikely. 


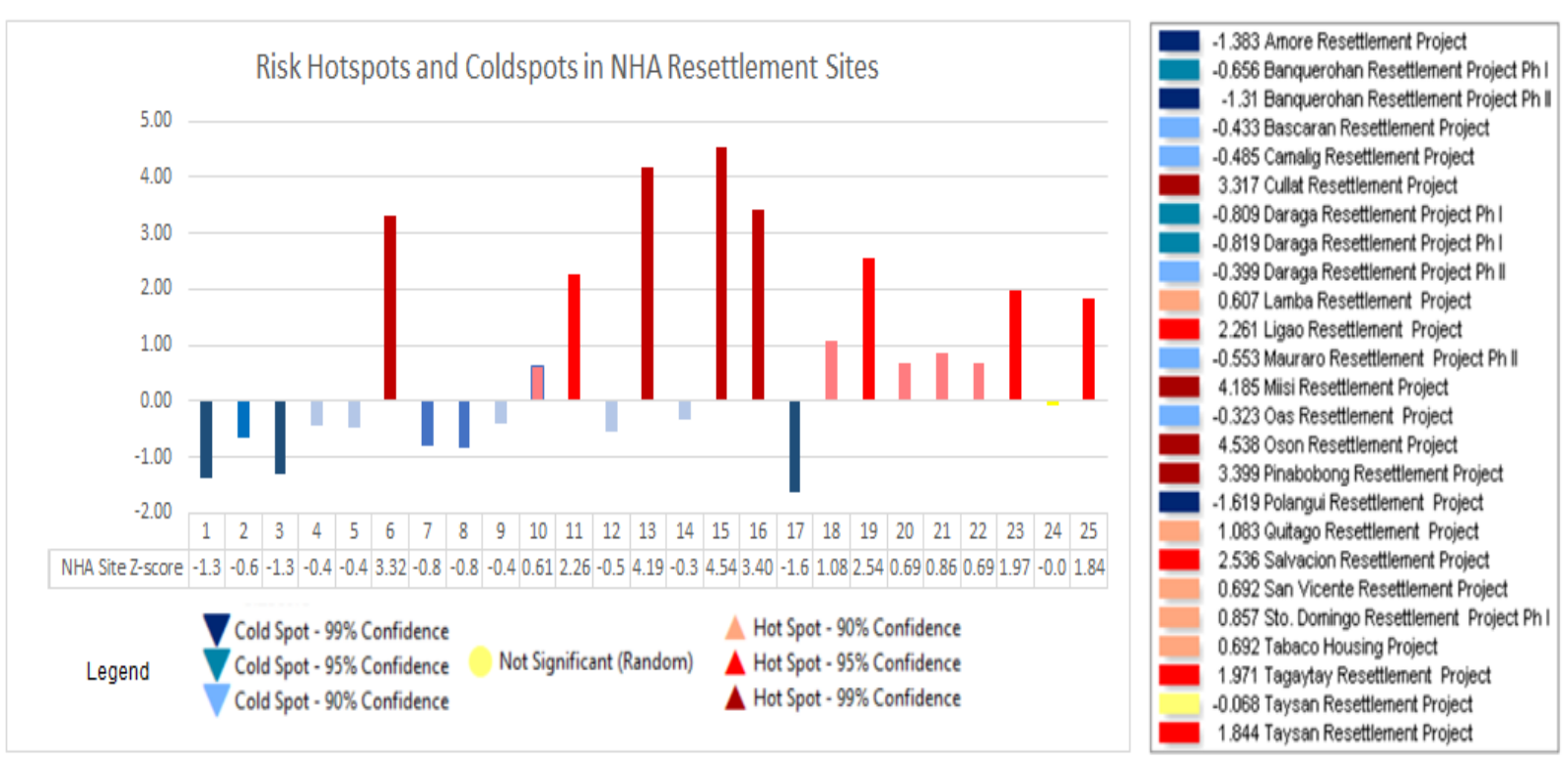

Fig. 11 Risk Realness in Resettlement Sites in Albay, Philippines

Fig. 11 presented the risk realities in terms of hotspot and coldspot to exemplify the results after overlay analysis. The risk reality are regarded as the z-scores and classification of hotspot and coldspot: Very Low indicating $95 \%$ to 99\% significantly coldspot or Very Low Risk Class (VL); Low indicating 90\% significantly coldspot or Low Risk Class (L); Moderate indicating random negative or positive $\mathrm{z}$-score values between $-89 \%$ to $89 \%$ confidence (M), High indicating $90 \%$ to $95 \%$ significantly hotspot or High Risk Class (H), and Rising Uncertainties indicating $99 \%$ significantly hotspot $(\mathrm{VH})$ determine whether spatial equality is likely or not.

In tallying the risk reality values in the resettlement sites in Albay as shown in Table 2, it was revealed that fourteen (13 significantly risk hotspot and 1 insignificant value) out of the twenty-five NHA resettlement sites suffered in terms of the risk reality z-scores quantity where risk reality regarded hotspot or coldspot; Phi hinted spreading risk in resettlement sites. Moreover, out of the fourteen resettlement sites, four significantly need attention to reduce their disaster risk, these sites are: Oson and Pinabobong, in Tabaco City; and Cullat and Miisi, in Daraga town. Of these four sites, Cullat is a unique case: the hexagonal bin where this spot coincides generally characterizes the neighborhood oh high values interpreted by the Getis-Ord Gi* statistical tool in ArcGIS 10.8 version.

Taking part in validating the precise location relative to the physical landscape where Cullat resettlement sits as shown in Fig. 12, it was learned the binned information on slope carries a generalized weight of 4 indicating a high landscape vulnerability value. This shows that more detailed information and smaller size of hexagonal bins can bring more variations that can improve outcomes. Consequently, Cullat resettlement site carries a higher z-score. Each hexagonal bin carries a specific numerical value regarded as Risk Reality function (multiple hazards, landscape vulnerability, passive exposure, preparedness, competency, and coping capacity). Furthermore, the result of this study acknowledges the limitations of data model carries the accuracies of 1:50000 scale input maps only to show that it fits for macro planning or risk rapid assessment. Merely the same approach in site selection may be adopted for micro planning or comprehensive risk assessment. 


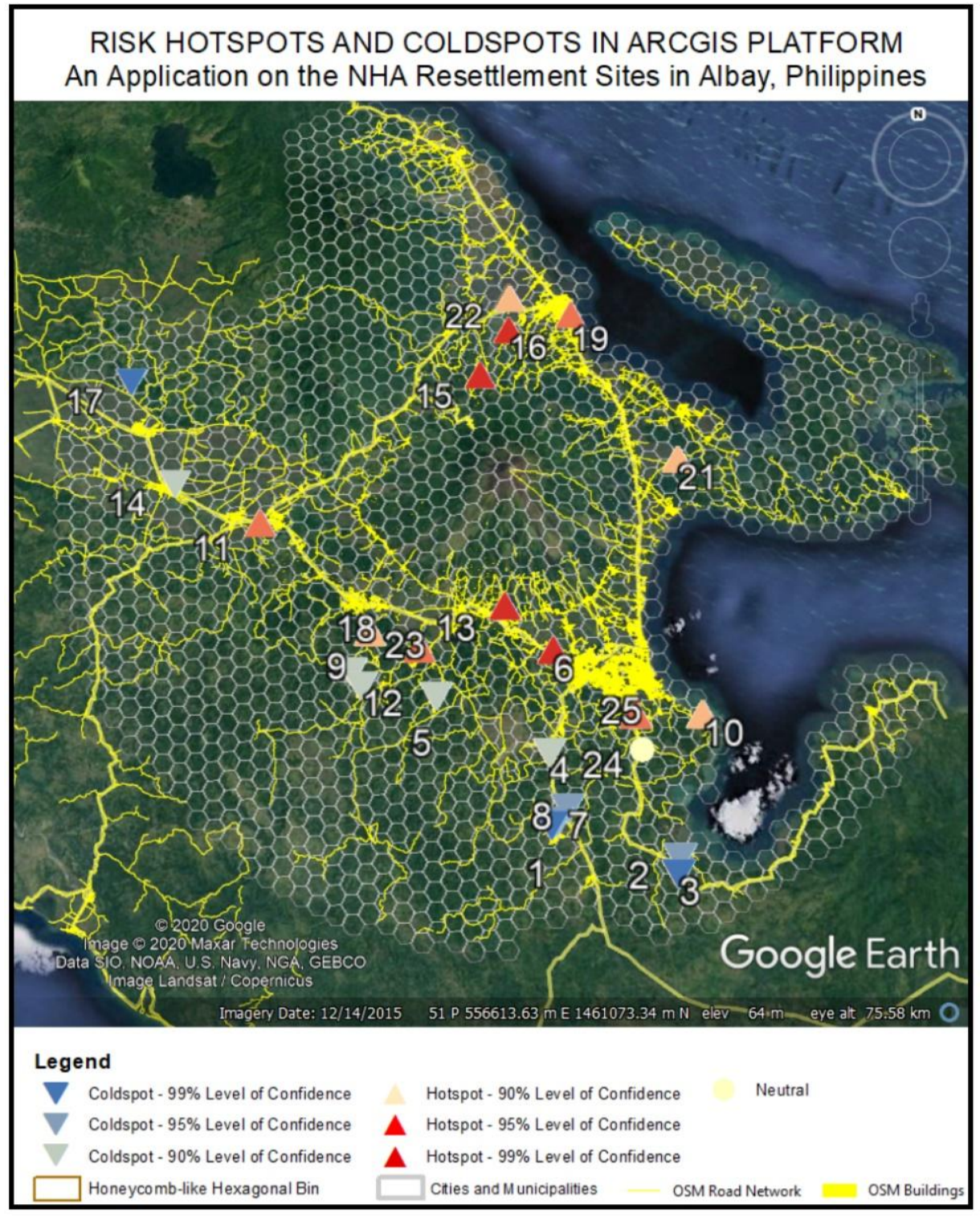

Fig. 12 Risk Reality in NHA Resettlement Sites in Albay, Philippines

\section{Conclusions}

Risk realities in terms of hotspots or coldspots is reliant on the receptive and responsive DRRM which entails an interdisciplinary thinking applying geospatial data science to characterize the multiple hazards, landscape vulnerable, and passive exposure hotspots or coldspots impacting Albay Province.

The researcher concluded that at least 14 resettlement sites in Albay will continue to suffer if the National Housing Authority, and other relevant agencies will delay relocating exposed residents to a safe space (with respect sill to the spatial equality), comfortable space (considering social justice), accessible sites approximately near the basic social services of the government. It further concluded that unreceptive and unresponsive mitigation actions affect whether the exposed population will become fully prepared or remain unprepared to withstand repetitive hazard events and the intrinsic effects of repetitive temporary evacuation of housing project beneficiaries. 
When stability is unlikely (at household, community level), meaning existing in an unsafe situation, there is a larger financial requirement to capacitate the local government units. Further, that while the risk realities in the 14 resettlement sites will continue to accrue based on the scientific findings (grounded by Metatheorems Objects on Stability, Risk Reality, and Risk Trends), more suffering will be experienced when risk becomes unbearable, where full recovery at any level is unlikely.

As the Risk-enhanced Resettlement Site Selection Model exhibited the realness of risk, spatial equality, social injustice, safe space, comfortable space, it allows visualization in the form of maps, graphs and tables revealing where receptive and responsive risk reduction is greatly needed. As a final point, risk reality is quantifiable and actionable, when supported by Geophilosophical reasoning supported by Metatheorem objects on risk reality where stability is the fulcrum to quantify receptive-responsive risk reduction interventions

\section{$494 \quad$ Availability of data and materials}

N. A.

\section{Competing interests}

N. A.

\section{Funding}

The author is a faculty member and recipient of the Bicol University Human Resource Development Program..

\section{Authors' contributions}

Abante, A. M. R. designed the Risk Reality Conceptual Space Model for her dissertation for the Doctor of Philosophy in Development Management to measure and prove the uniqueness of risk, residual risk and extraneous errors that are logical to the concept of assessing risk reality (conceptual space grounded by geographic concepts) phenomenon.

Abante, A. M. R. conceptualized the Risk Reality Isosceles $\Delta$ Grounded by Schoen Golden Triangle for her dissertation for the Doctor of Philosophy in Development Management to prove risk reality is measurable.

Abante, A. M. R. conceptualized the Risk Reality Circle Grounded by Fibonacci Golden Ratio and Schoen Golden Triangle for her dissertation for the Doctor of Philosophy in Development Management to prove that stability changes as it pivots the geocentric center which hinted where the resiliency is hinged as well as proving the relationships of the vertices of resiliency that are interconnected and arranged opposite of the with the stability baselines of all isosceles triangles where the asymptotic segments hinted at receptive and responsive risk reduction.

Abante, A. M. R. created the Vertices of Resiliency Index Grounded by Grounded by Golden Ratio and Triangle

Abante, A. M. R. designed the computational DRRM-Circumspectial Isometric Stages Framework Model needed to analyze the resulting risk reality z-scores to assess risk realness stored and sorted in hexagonal bins. This research output is part of her dissertation manuscript for the Doctor of Philosophy in Development Management.

Abante, A. M. R. crafted the risk-enhanced resettlement site selection modeling, a technique to review the risk realness that is reliant to the computational DRRM-Circumspectial Isometric Stages Framework Model. The National Housing Authority resettlement sites in Albay, Philippines were reviewed to test the proposed site selection model parameters for settlement or resettlement sites as well as examined the actuality of 
Geophilosophical realism of assessing the potential risk recurring in addition to the accumulated residual risk from past hazard events.

Abante, A. M. R. designed the Hexagonal Binning technique to store the risk hotspot or coldspot information to mimic the risk reality in Albay and developed the geospatial information data model to demonstrate that the complexities in quantifying risk reality is doable.

Abante, A. M. R. devised the geophilosophical Metatheorem objects in her dissertation for the Doctor of Philosophy in Development Management to prove the mathematical logic that demonstrates the risk realness varies at different extents of stability. Her dissertation proved that risk trend is a calculated risk reality (risk hotspot) in addition to the residual risk $(\Delta R)$ and $\operatorname{Phi}(\varphi)$ when risk exceeds 125-unit quantity.

\section{Acknowledgements}

The road to completing the dissertation was fraught with many obstacles and challenges that were overcome due both to the persistence and motivation of its maker, and the support of all those who have given much more than their time and minds. I dedicate this section to such extraordinary persons who have taken away much from them, only to give more to others. The creation and refinement of knowledge is no small feat and can only be done with the support of others. My adviser in this dissertation, Dr. Jose Leandro A. Lanuzo generously imparted his unique perspectives and allegories on theories and concepts of development management. His insights greatly improved my own views and understanding of the discipline that surround my work. His willingness to share his mind is a great act of generosity that I am truly grateful for. A dissertation, however, is a complex work of art and skill that also requires expertise in specific disciplines. I am fortunate to have had the guidance of my external panelists Dr. Encarnacion N. Raralio, and her husband Dr. Pedro Raralio, for their sharing technical expertise to complete this manuscript. Among them, I also extend my greatest thanks to Ms. Arlene E. Dayao, for her invaluable expertise in geosciences. Dissertation Committees are often viewed as gates or hurdles to overcome, but in my case, I have been graced by one which has often been the source of direction and motivation. Atty. Alex B. Nepomuceno as the Chairperson, and the members: Atty. Joseph L. Bartolata, PhD, Dr. Benedicto B. Balilo, DIT, Ar.EnP. Encarnacion N. Raralio, PhD. and Arlene E. Dayao, MSc. have my gratitude for their unceasing willingness to see me through this achievement. Their wisdom was a torch that lit the way through a familiarly dark parth. I also wish to acknowledge the open-source data of NAMRIA, PhilGIS, Project NOAH, PhilLIDAR, DENR-MGB, DENR-MGB, PHIVOLCS, and Open Street Maps and its contributors. The data they continue to provide are valuable sources of information for researchers in my field. Also, the complex analyses conducted in this paper would have been difficult to implement without the personal use license and access provided by the Environmental Science Research Institute (ESRI). I am also dedicating this section to a few more people, who, in their own capacities as colleagues and friends, have been instrumental to the completion of this work. Dr. Arnulfo M. Mascariñas, Bicol University President; Dr. Helen M. Llenaresas, Vice-President for Academic Affairs; Engr. Amelia B. Gonzales, PhD, BUCENG Dean; Dr. Noemi L. Ibo, JMRIGD Director; and Dr. Antonio P. Payonga, BU Graduate School Dean. They work tirelessly to transform the University into a world-class university. Engr. Teodora Bandojo from the National Housing Authority has my great thanks for providing the data on NHA resettlement sites. Other forms of support and assistance also helped me in this endeavor: my son EnP. Carlo Gabriel R. Abante for his technical support; my student Louie Jennidene V. Ramirez for her drawings and illustrations; and my eldest son Paolo Gabriel for accompanying me during my site visits. Their voluntary efforts are greatly appreciated. To all my classmates in the Development Management program, thank you for the encouragement to complete this work; To all my friends who stayed by my side during all the difficult times, thank you for the friendship; To my mother Heidi L. Rico, thank you for your persistence to motivate me to finish my doctoral degree; To my children Paolo, Carlo, Marco, and Marietoni, thank you for your unconditional love; I dedicate this manuscript to my late husband Anthony, who was my silent confidant and critic. His openness and patience never wavered, despite his Parkinson's Disease. Until his very end, he remained my closest adviser. Above all, I dedicate this dissertation to The Almighty God, the source of all that I have. May my work and my achievements in life always serve the benefit of his creation. 


\section{Authors' information}

The author completed Doctor of Philosophy in Development Management at the Jesse M. Robredo Institute, Bicol University in July 4, 2020; a holder of Professional Masters in Geoinformatics with Specialization in Development and Maintenance of Geographic Information Systems, International Institute for Aerospace Surveys and Earth Sciences (ITC), Enschede, The Netherlands; a recipient of Netherlands Fellowship Program (NFP) in 1997; a graduate of Applied Geodesy and Photogrammetry, University of the Philippines, Training Center for Applied Geodesy and Photogrammtery in 1992; and a graduate of Bachelors of Science in Civil Engineering, Bicol University College of Engineering, Legazpi City in 1989. Presently connected as a faculty in BU College of Engineering. She authors researches that focus in applying geoinformatics in environmental planning and disaster risk reduction. She published four papers in 2018-2019. She received 2 best paper in Bicol University in 2018-2019 and recently attended various training on basic meteorology, flood risk modeling, Safe and Resilient Cities, geomatics and planning, remote sensing, unmanned aerial vehicle road mapping, space science and technology, etc. The author is licensed to practice environmental planning, geodetic engineering and civil engineering in the Philippines.

\section{References}

${ }^{1}$ Abante, A. M. R. (2020). Unpublished Dissertation entitled "Geophilosophical Perspective on Socio-spatial Fuzzy Reality Phenomenon". Bicol University, Legazpi City Philippines

${ }^{2}$ Pellini, A., Jabar, M., Era, M., \& Erasga, D. (2013). Towards policy-relevant science and scientifically informed policy: Political economy of the use of knowledge and research evidence.

${ }^{3}$ Gerona, D. M. (2013). Guinobatan

${ }^{4}$ Abante, A. M. R., \& Balilo Jr, B. B. (December 2018). Resource Location-Intelligence Model Conceptualized for Mayon Volcano Danger Zones in Albay, Philippines. International Journal of Computing Sciences Research, 2(2), 55-67.

${ }^{5}$ Gärdenfors, P. (2004). Conceptual spaces: The geometry of thought. MIT press.

${ }^{6}$ Abante, A. M. R. (December 2018). Understanding Preparedness Insufficiency in the Context of DRRM: A Case Study in Malinao, Albay, Philippines. In Recent Advances in Geo-Environmental Engineering, Geomechanics and Geotechnics, and Geohazards (pp. 497-501). Springer, Cham.

${ }^{7}$ Woodard, B. (2013). On an ungrounded earth: Towards a new geophilosophy. punctum books.

${ }^{8}$ Woodward, K. (2016). Geophilosophy. International Encyclopedia of Geography: People, the Earth, Environment and Technology: People, the Earth, Environment and Technology, 1-8.

${ }^{9}$ Abante, A. M. R. \& Abante, C. G. R. (December 2019). TOPOPHILIA-EXPOSURE CENTRAL SPACE CONCEPT MODEL, Int. Arch. Photogramm. Remote Sens. Spatial Inf. Sci., XLII-4/W19, 1-8,

${ }^{10}$ Abante, A. M. R., \& Abante, C. G. R. (2018, February). Sensitive Land Use Planning, Malinao, Albay, Philippines. In IOP Conference Series: Earth and Environmental Science (Vol. 123, No. 1, p. 012001). IOP Publishing

${ }^{11}$ Birkmann, J. (2006). Measuring vulnerability to promote disaster-resilient societies: Conceptual frameworks and definitions. Measuring vulnerability to natural hazards: Towards disaster resilient societies, 1, 9-54.

${ }^{12}$ Birkmann, J., \& Wisner, B. (2006). Measuring the unmeasurable: the challenge of vulnerability. UNU-EHS.

${ }^{13}$ King, L. J. (2020). Central place theory.

${ }^{14}$ Scott, L. M., \& Janikas, M. V. (2010). Spatial statistics in ArcGIS. In Handbook of applied spatial analysis (pp. 27-41). Springer, Berlin, Heidelberg.

${ }^{15}$ Worboys, M. F., \& Duckham, M. (2004). GIS: a computing perspective. CRC press.

${ }^{16}$ Rolf, A., \& de By, R. A. (2000). Principles of geographic information systems. The International Institute for Aerospace Survey and Earth Sciences (ITC), Hengelosestraat, 99.

${ }^{17}$ Getis, A., \& Getis, J. (1966). Christaller's central place theory. Journal of Geography, 65(5), 220-226.

18 Ord, J. K., \& Getis, A. (1995). Local spatial autocorrelation statistics: distributional issues and an application. Geographical analysis, 27(4), 286-306.

${ }^{19}$ Pearson, L., \& Pelling, M. (2015). The UN Sendai framework for disaster risk reduction 2015-2030: Negotiation process and prospects for science and practice. Journal of Extreme Events, 2(01), 1571001.

${ }^{20}$ Quito Declaration on Sustainable Cities and Human Settlements for All. 
${ }^{21}$ IPCC Second Assessment Report WGIII - Climate Change 1995: Economic and Social Dimensions of Climate Change

${ }^{22}$ National Disaster Risk Reduction and Management Plan (NDRRMP) 2011 - 2028

${ }^{23}$ Flood Forecasting and Flood Hazard Mapping for Bicol River Basin, Disaster Risk Exposure and Assessment for Mitigation (DREAM), DOST Grants in-Aid Program, 61 pp.

${ }^{24}$ Joint DENR-DILG-DND-DPWH-DOST Adoption of Hazard Zone Classification on (2014)

25 Assessment of Disaster Risk Reduction and Management (DRRM) at the Local Level. Commission on Audit (2014)

${ }^{26}$ Daep, C. D. (2011) Bicol University Graduate School Unpublished Dissertation entitled "The Implementation of the Disaster Risk Reduction Management Program in the Province of Albay". Bicol University Dissertation.

27 Hofmann, M. (2007). Resilience. A formal approach to an ambiguous concept (Doctoral dissertation, Diplomarbeit, FachbereichfürMathematik und Informatik, Freie Universität Berlin).

${ }^{28}$ Couclelis, H. (2005). "Where has the future gone?" Rethinking the role of integrated land-use models in spatial planning. Environment and planning A, 37(8), 1353-1371.

${ }^{29}$ Gregory, D., Johnston, R., Pratt, G., Watts, M., \& Whatmore, S. (Eds.). (2011). The dictionary of human geography. John Wiley \& Sons.

${ }^{30}$ Hadjimichalis, C. (2011). Uneven geographical development and socio-spatial justice and solidarity: European regions after the 2009 financial crisis. European Urban and Regional Studies, 18(3), 254-274.

${ }^{31}$ Situational Report No.57 re Mayon Volcano Eruption - ndrrmc.

32 Aubrecht, C., Özceylan, D., Steinnocher, K., \& Freire, S. (2013). Multi-level geospatial modeling of human exposure patterns and vulnerability indicators. Natural Hazards, 68(1), 147-163.

${ }^{33}$ Carreño, M. L., Cardona, O. D., \&Barbat, A. H. (2007). A disaster risk management performance index. Natural Hazards, 41(1), 1-20.

34 Gregory, D. (1989). Areal differentiation and post-modern human geography. In Horizons in human geography (pp. 67-96). Palgrave, London.

${ }^{35}$ Birkmann, J., \& Wisner, B. (2006). Measuring the unmeasurable: the challenge of vulnerability. UNU-EHS.

${ }^{36}$ Cutter, S. L., Boruff, B. J., \& Shirley, W. L. (2003). Social vulnerability to environmental hazards. Social science quarterly, 84(2), 242-261.

${ }^{376}$ Cutter, S. L. (2003). The vulnerability of science and the science of vulnerability. Annals of the Association of American Geographers, 93(1), 1-12.

${ }^{38}$ Cutter, S. L., Boruff, B. J., \& Shirley, W. L. (2003). Social vulnerability.

${ }^{39}$ Birkmann, J., Cardona, O. D., Carreño, M. L., Barbat, A. H., Pelling, M., Schneiderbauer, S., ... \& Welle, T. (2013). Framing vulnerability, risk and societal responses: the MOVE framework. Natural hazards, 67(2), 193-211.

${ }^{40}$ Cardona, O. D., van Aalst, M. K., Birkmann, J., Fordham, M., McGregor, G., \&Mechler, R. (2012). Determinants of risk: exposure and vulnerability.

${ }^{41}$ Cuevas, S. C., Peterson, A., Robinson, C., \& Morrison, T. H. (2016). Institutional capacity for long-term climate change adaptation: evidence from land use planning in Albay, Philippines. Regional environmental change, 16(7), 2045-2058.

${ }^{42}$ Salceda, J. S. (2012). Adapting to climate change: Strategies of Albay, Philippines. Agriculture and Development Notes on Climate Change Adaptation, 2.

${ }^{43}$ Resilience in Albay, Philippines. Climate Change Adaptation and Disaster Risk Reduction: An Asian Perspective, 237-259.

${ }^{44}$ Andam Lahar: Anticipation Action for Lahar Risks Preparedness Module for Rain Induced Lahar.

${ }^{45}$ Contreras, D., Blaschke, T., \& Hodgson, M. E. (2017). Lack of spatial resilience in a recovery process: Case L'Aquila, Italy. Technological forecasting and social change, 121, 76-88.

${ }^{46}$ Dikeç, M. (2001). Justice and the spatial imagination. Environment and planning A, 33(10), 1785-1805.

47 Dupont, V. (2004). Socio-spatial differentiation and residential segregation in Delhi: a question of scale? Geoforum, 35(2), 157-175.

${ }^{48}$ International Forum for Social Development Social Justice in an Open World The Role of the United Nations. 
Figures

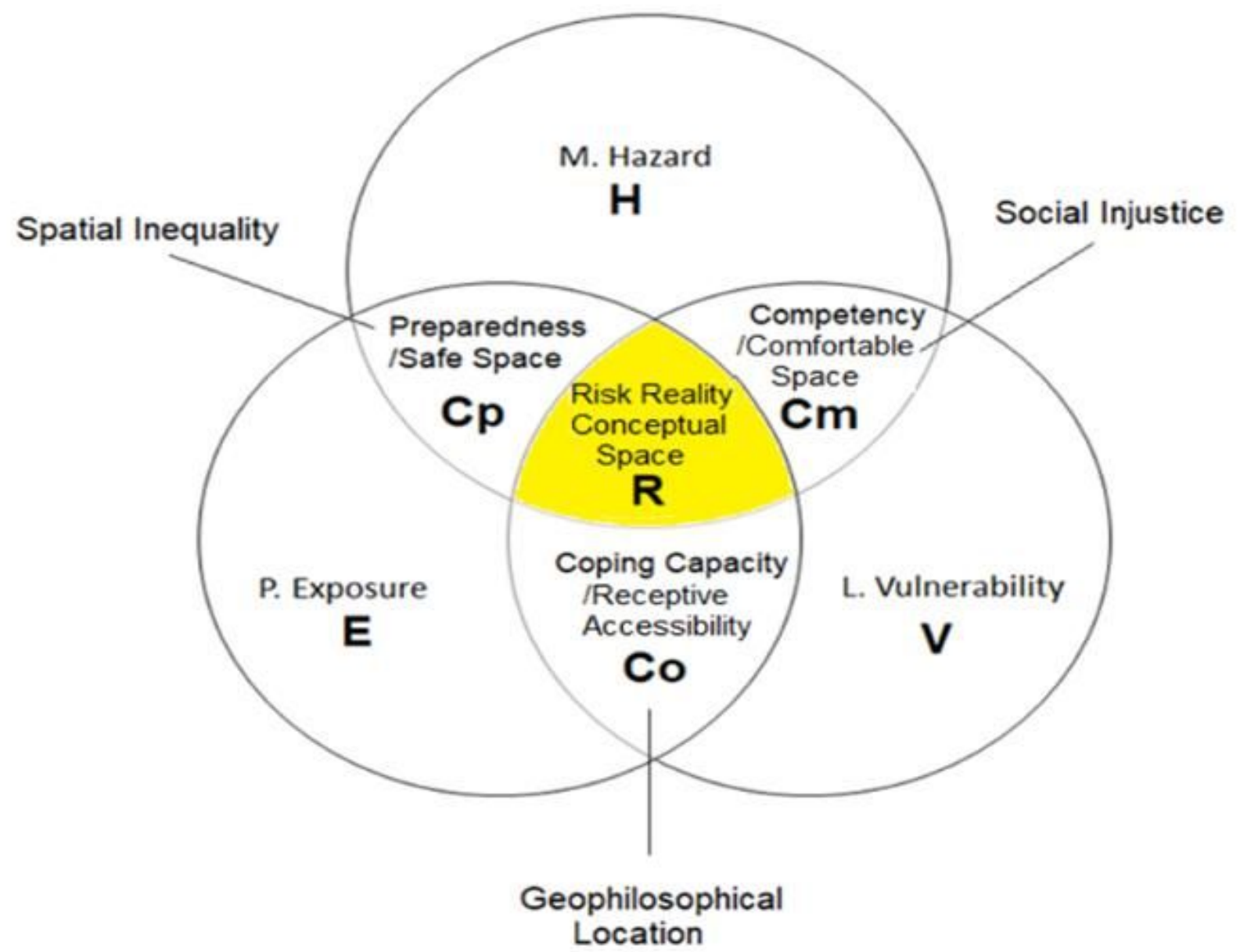

Figure 1

Risk Reality Conceptual Space (Abante, 2020) 


\begin{tabular}{|c|c|c|c|c|c|c|}
\hline Risk Reality & $\begin{array}{r}\text { Class } \\
\text { Description }\end{array}$ & $\begin{array}{c}\text { Very High Risk } \\
95 \text { to } 99 \% \text { Hotspot }\end{array}$ & $\begin{array}{c}\text { High Risk } \\
90 \text { to } 95 \% \text { Hotspot }\end{array}$ & $\begin{array}{l}\text { Moderate } \\
\text { Neutral }\end{array}$ & $\begin{array}{c}\text { Low Risk } \\
90 \text { to } 95 \% \text { Coldspot }\end{array}$ & $\begin{array}{c}\text { Very Low Risk } \\
95 \text { to } 99 \% \text { Coldspot }\end{array}$ \\
\hline & Quantity & $\geq 500$ & $\geq 450<500$ & $\geq 180<450$ & $\geq 60<180$ & $<60$ \\
\hline Multiple Hazards & Description & $\begin{array}{c}\text { Very High Multiple } \\
\text { Hazards }\end{array}$ & High & Moderate & Low & Very Low \\
\hline I andscane & Quantity & & $\geq 10<13$ & $\geq 8<10$ & $\geq 5<8$ & $<5$ \\
\hline Vulnerability & Description & Critical Condition & $\begin{array}{l}\text { Somewhat Unsafe } \\
\text { Condition }\end{array}$ & Neutral & Somewhat Safe & Stable Space \\
\hline & Quantity & 5 & 4 & 3 & 2 & 1 \\
\hline Passive Exposure & Description & Critical location & Unsafe location & Neutral & $\begin{array}{l}\text { Somewhat Safe } \\
\text { Location }\end{array}$ & Safe Location \\
\hline & Quantity & 5 & 4 & 3 & 2 & 1 \\
\hline Preparedness & Description & Unprepared & $\begin{array}{l}\text { Insufficient } \\
\text { Preparedness }\end{array}$ & Neutral & Somewhat Prepared & Prepared \\
\hline & Quantity & 5 & 4 & 3 & 2 & 1 \\
\hline Competency & Description & Incompetent & $\begin{array}{l}\text { Somewhat } \\
\text { Incompetent }\end{array}$ & Neutral & $\begin{array}{l}\text { Somewhat } \\
\text { Competent }\end{array}$ & Competent \\
\hline & Quantity & 5 & 4 & 3 & 2 & 1 \\
\hline Coping Capacity & Description & In bad condition & $\begin{array}{c}\text { Poor Coping } \\
\text { Capacity }\end{array}$ & Neutral & $\begin{array}{l}\text { Somewhat High } \\
\text { Coping Capacity }\end{array}$ & $\begin{array}{l}\text { High Coping } \\
\text { Capacity }\end{array}$ \\
\hline
\end{tabular}

\section{Figure 2}

Risk Reality Binning Parameters (Abante, 2020) 


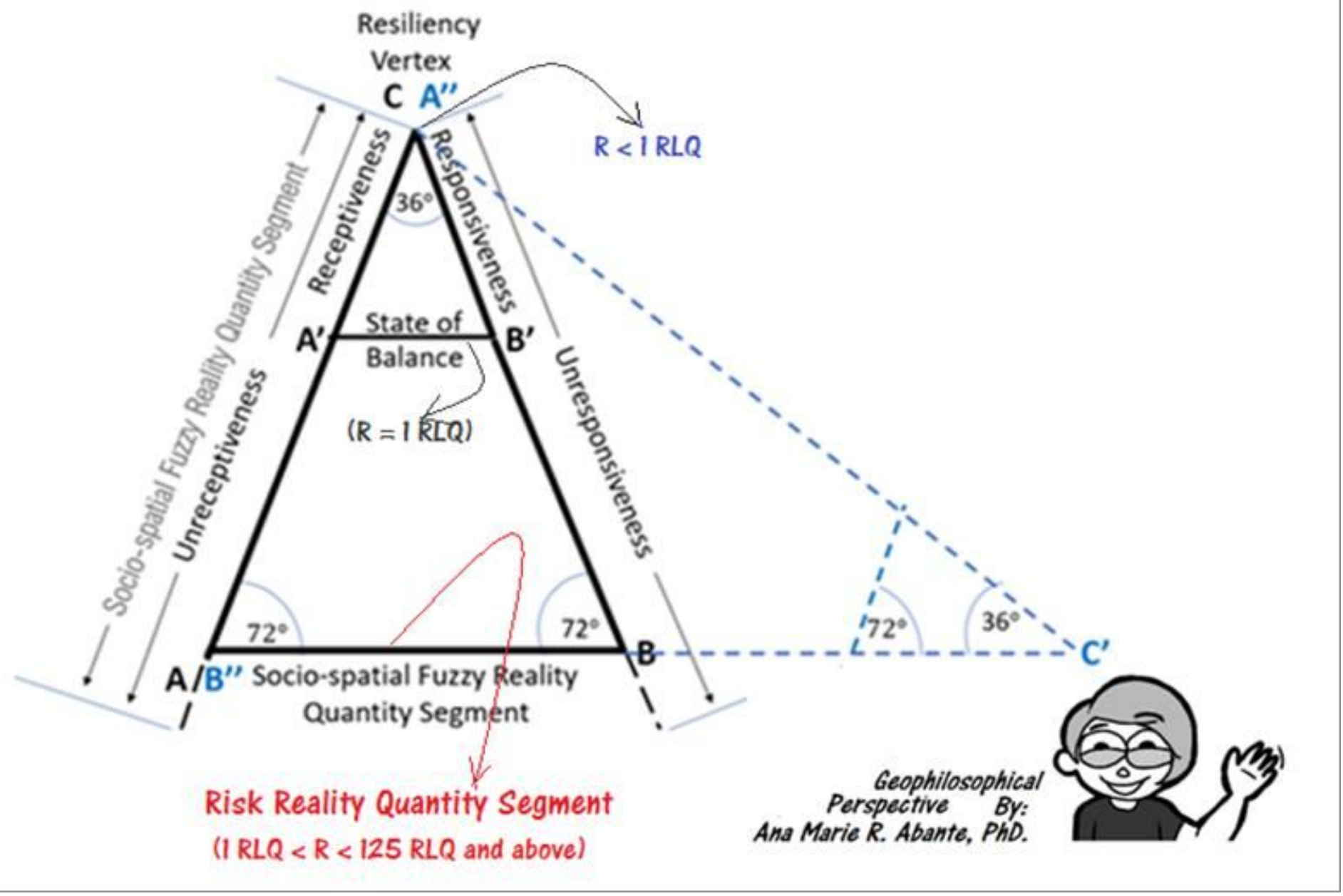

Figure 3

Risk Reality Isosceles $\Delta$ Grounded by Schoen $\Delta$ (Abante, 2020) 


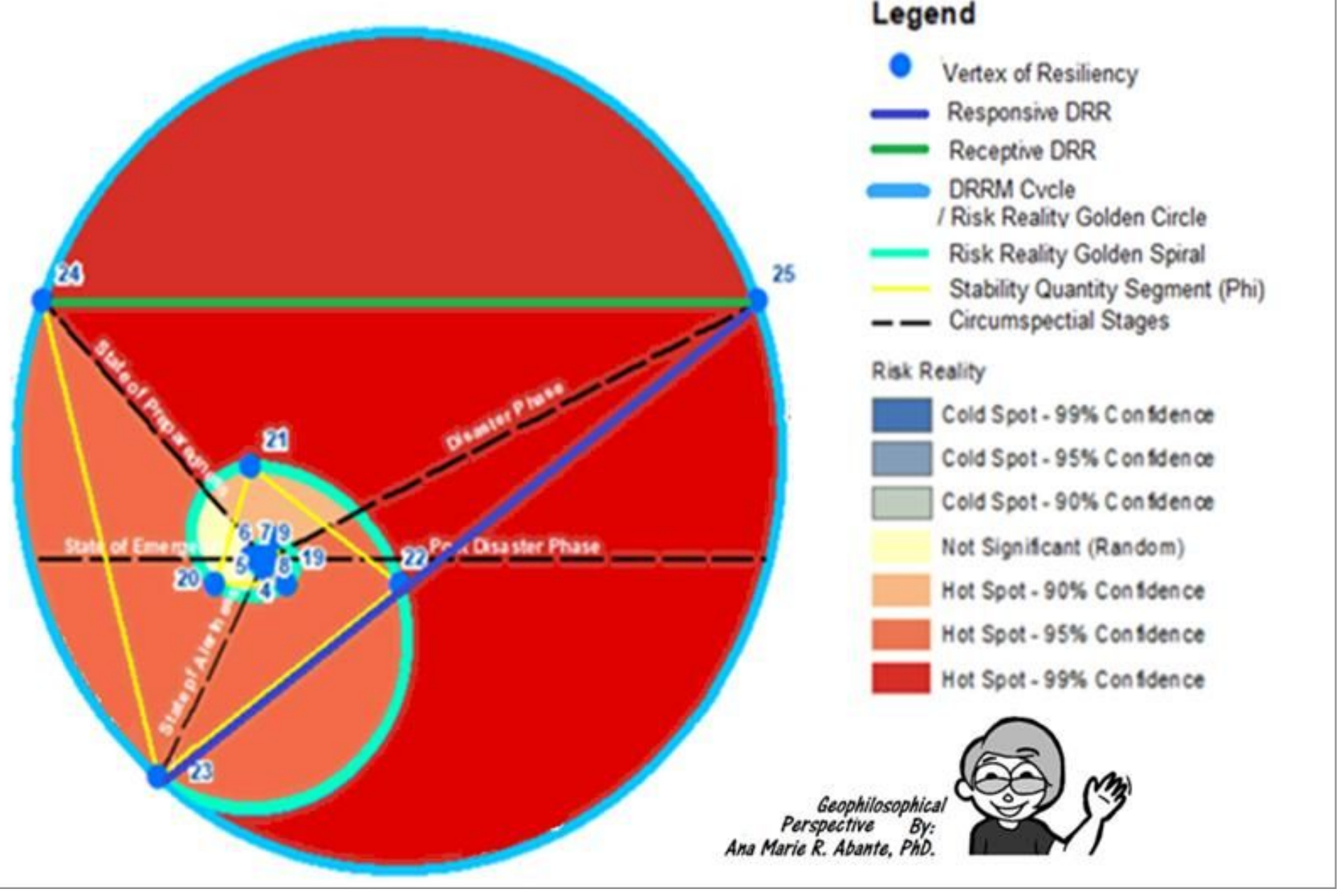

\section{Figure 4}

Risk Reality Circle Grounded by Fibonacci Golden Ratio and Schoen Golden Triangle (Abante, 2020) 


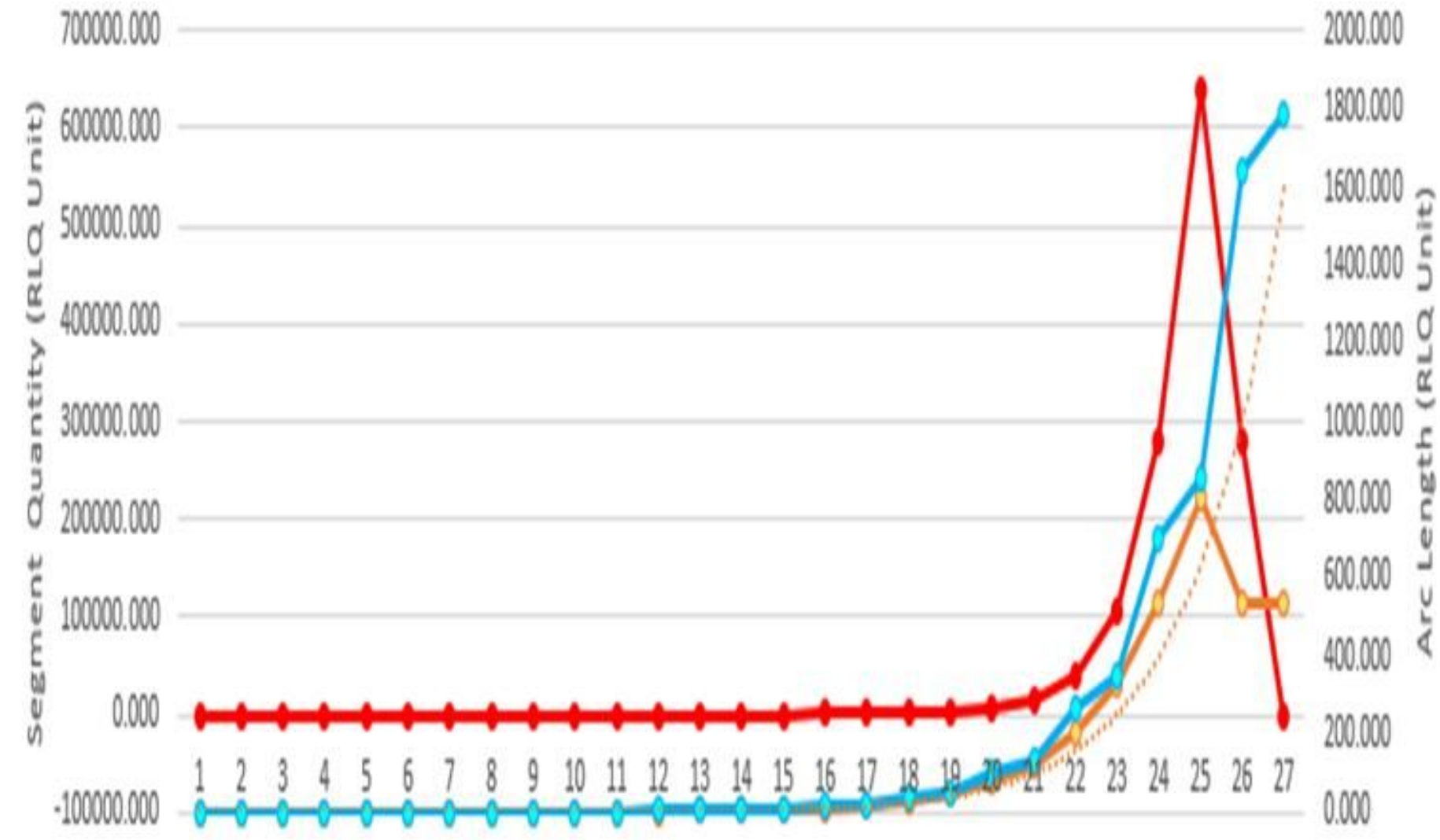

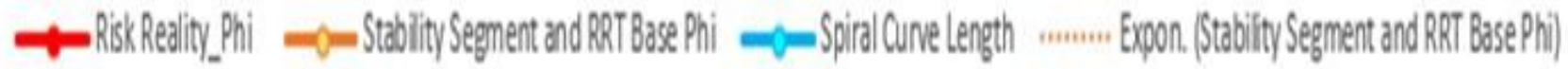

\section{Figure 5}

Risk Reality Quantity Chart (Abante, 2020) 


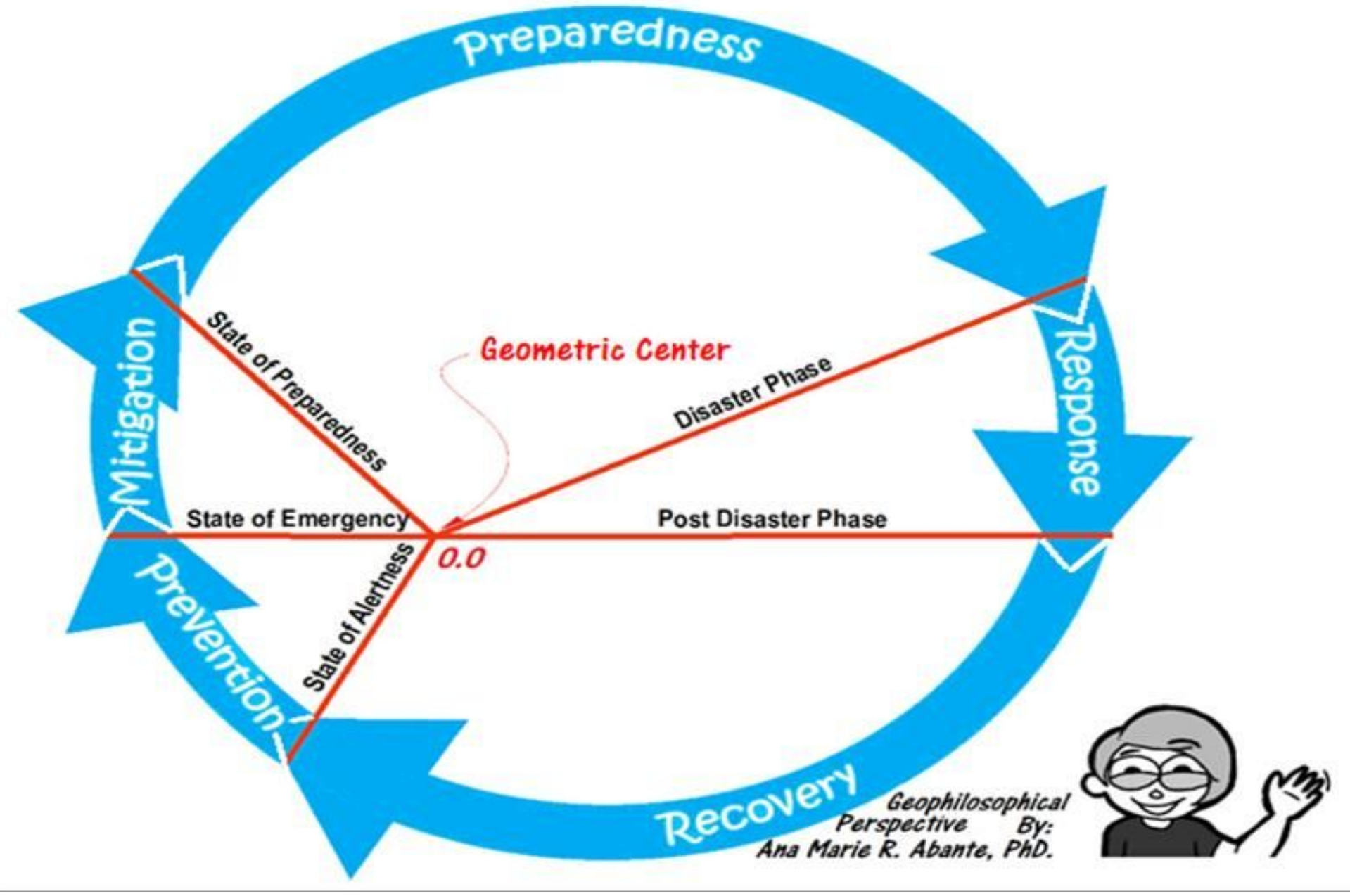

Figure 6

DRRM-Circumspectial Isometric Stages Parameter (Abante, 2020)
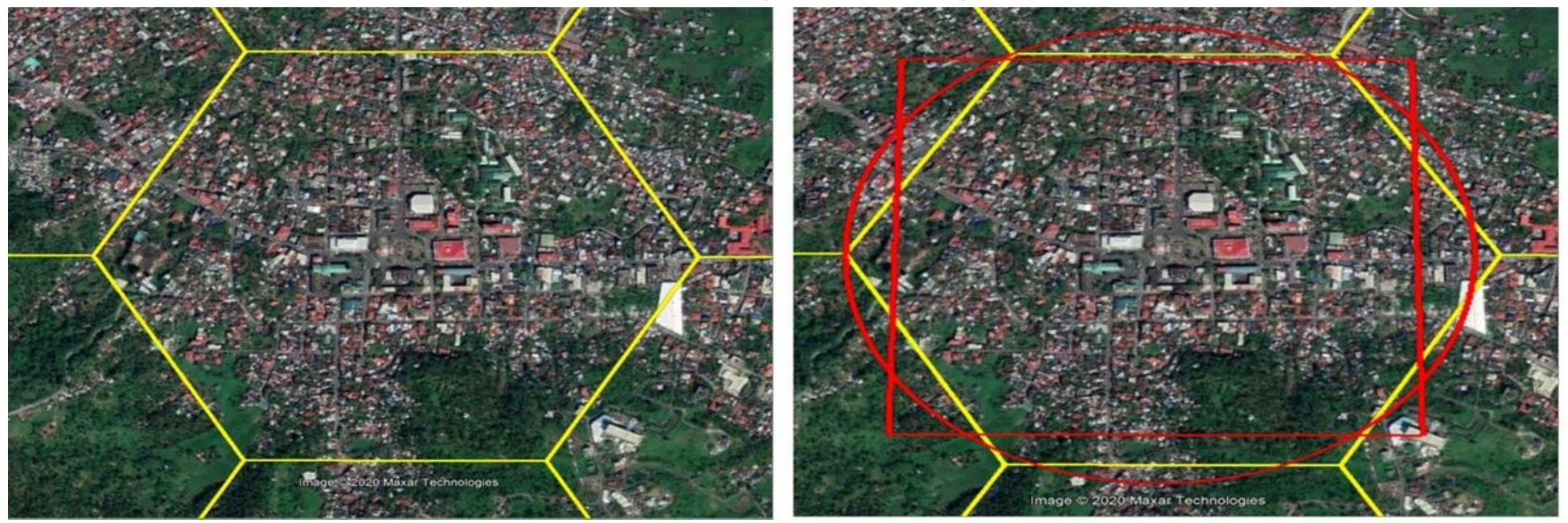

Figure 7

Tessellated Hexagonal Bins (Polygons) 


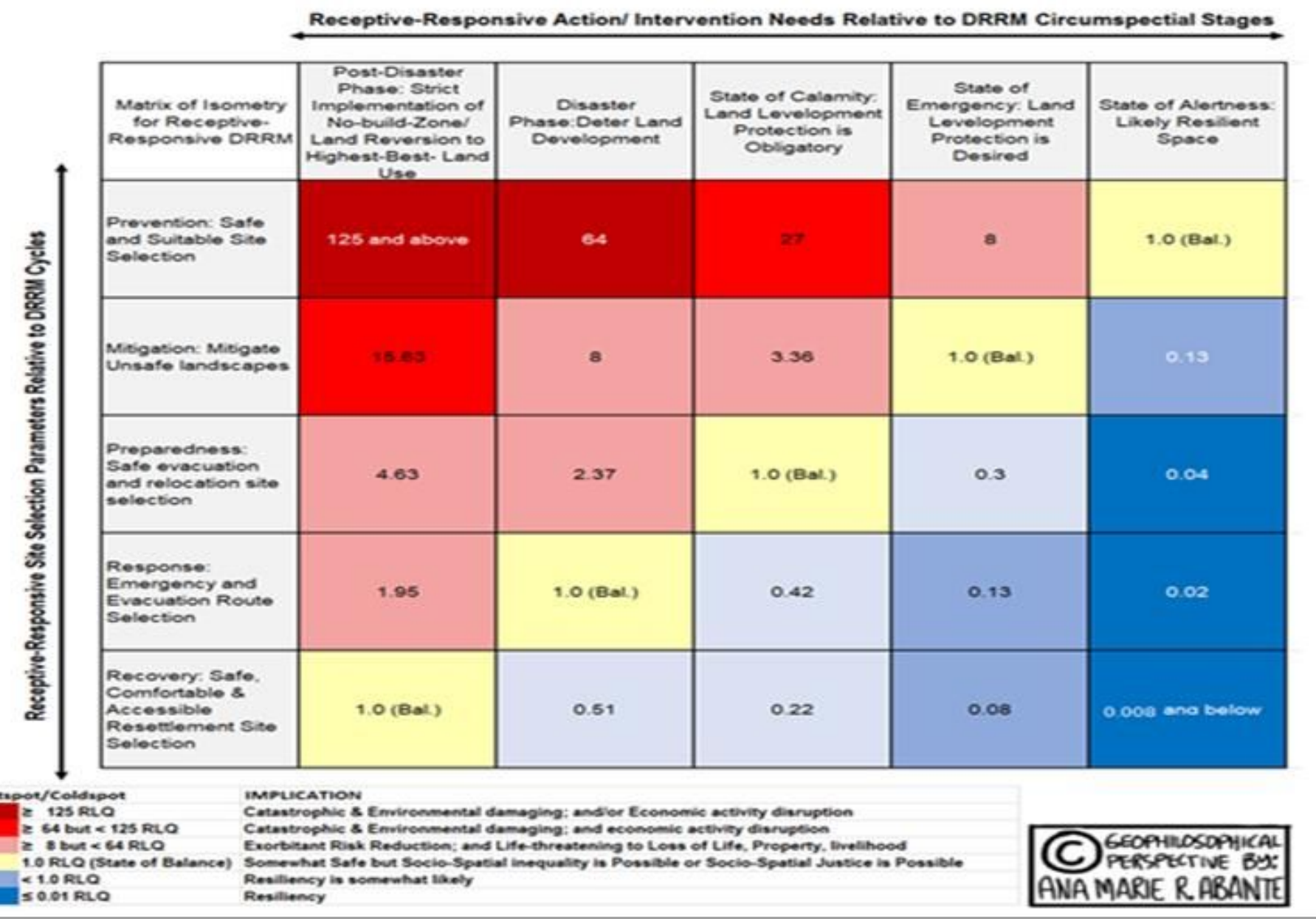

Figure 8

Receptive-Responsive DRR Isometric Index (Abante, 2020) 


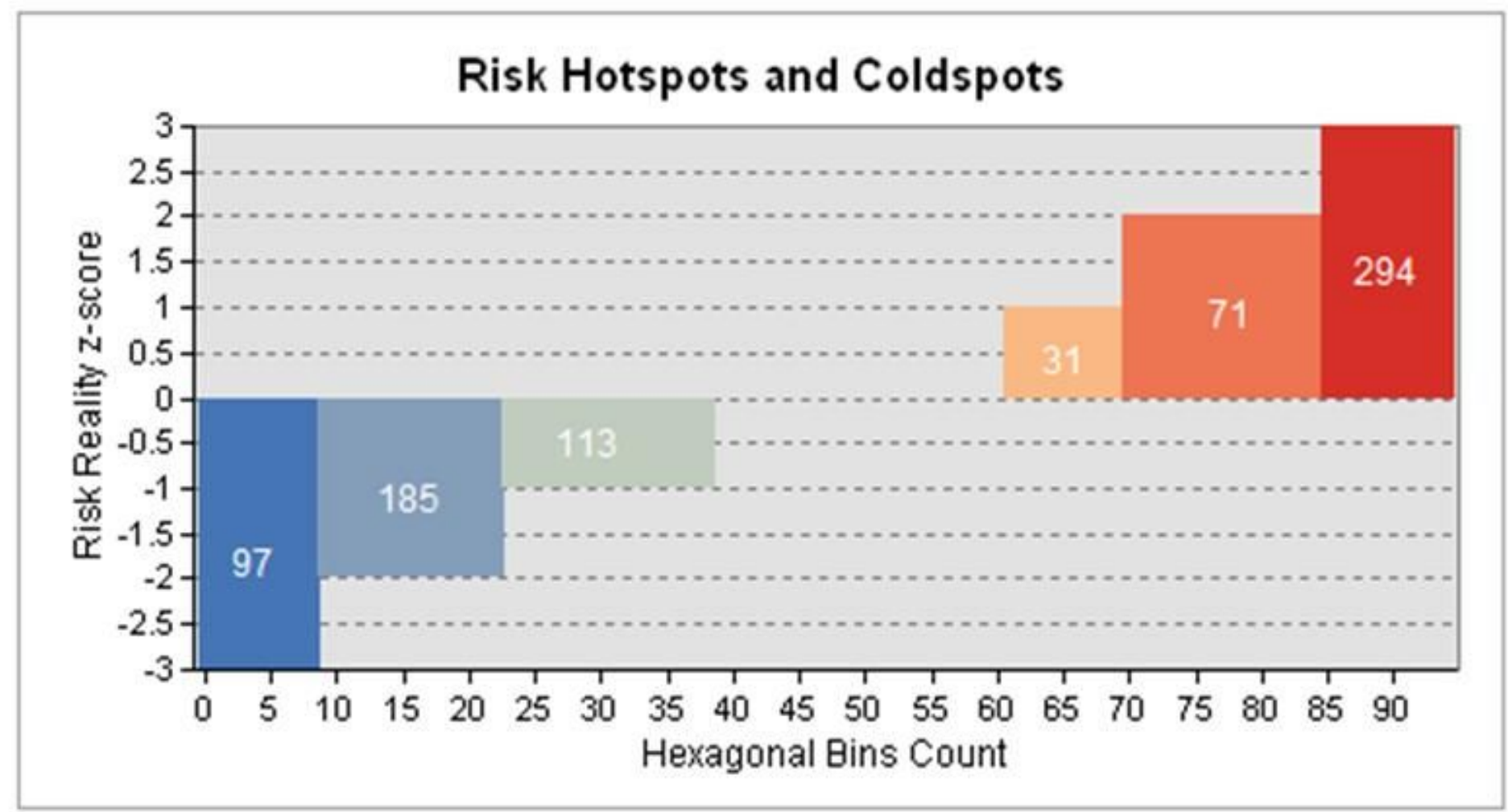

Cold Spot - $99 \%$ Confidence

$\square$ Cold Spot - $95 \%$ Confidence

$\square$ Hot Spot - $90 \%$ Confidence

$\square$ Cold Spot - $90 \%$ Confidence

$\square$ Not Significant

$\square$ Hot Spot - 95\% Confidence

Hot Spot - $99 \%$ Confidence

\section{Figure 9}

Risk Hotspots and Coldspots Bin Count 
Cold Spot - $99 \%$ Confidence

Cold Spot - 95\% Confidence $\square$ Cold Spot - $90 \%$ Confidence $\square$ Not Significant

$\square$ Hot Spot - $90 \%$ Confidence

Hot Spot - $95 \%$ Confidence

Hot Spot - $99 \%$ Confidence
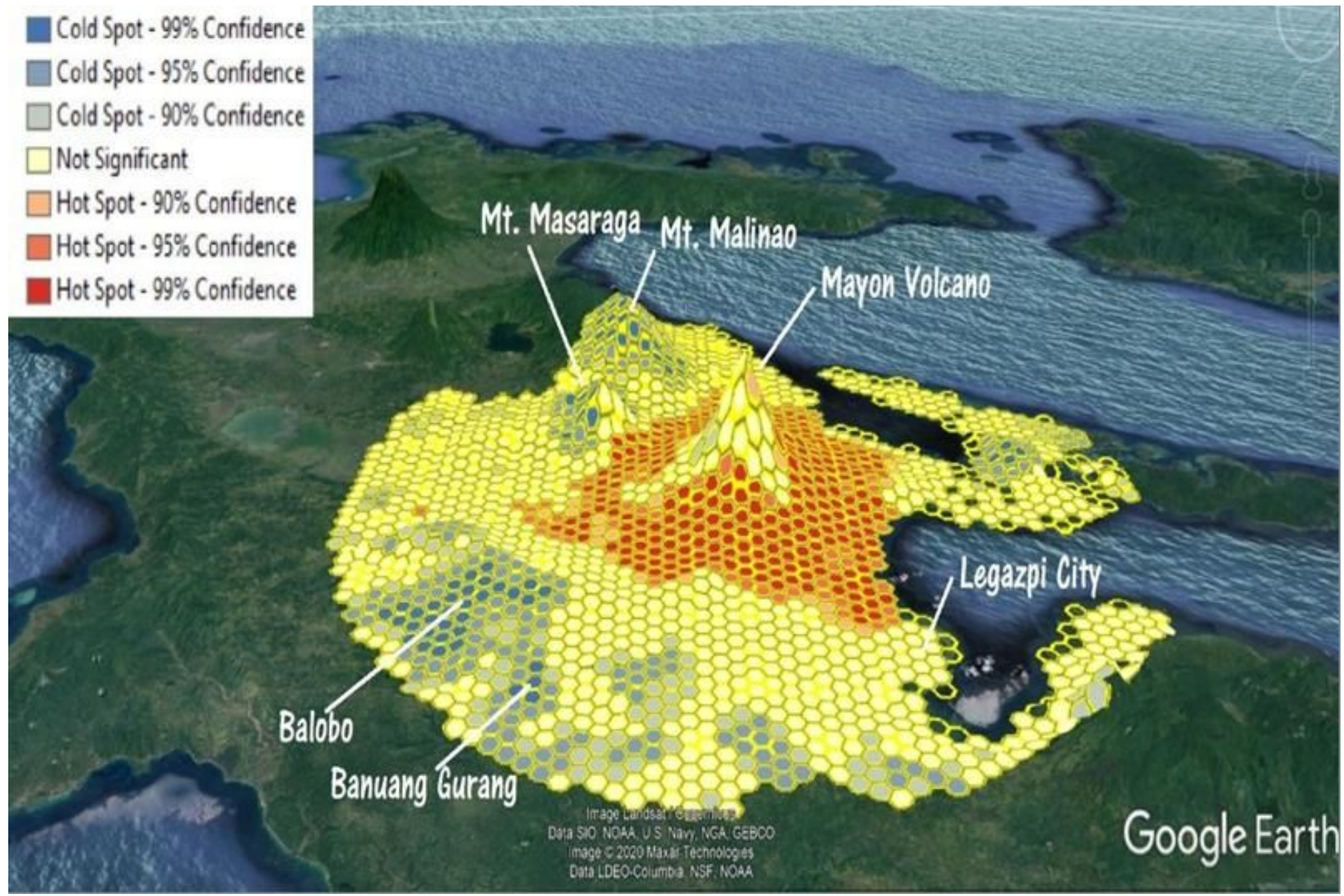

Figure 10

Risk Hotspot and Coldspot Tessellated Bins Visualization in Google Earth Platform 


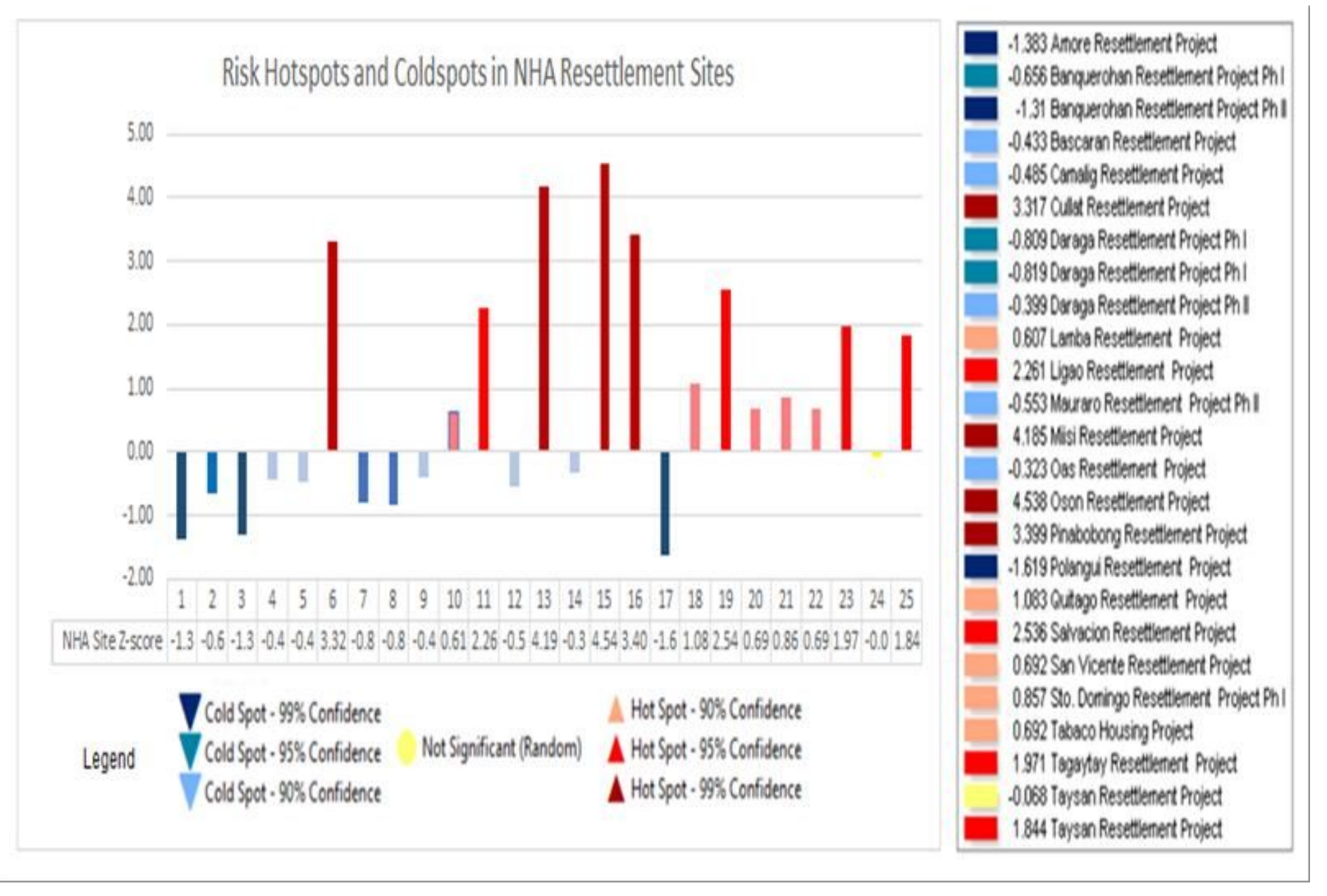

\section{Figure 11}

Risk Realness in Resettlement Sites in Albay, Philippines 


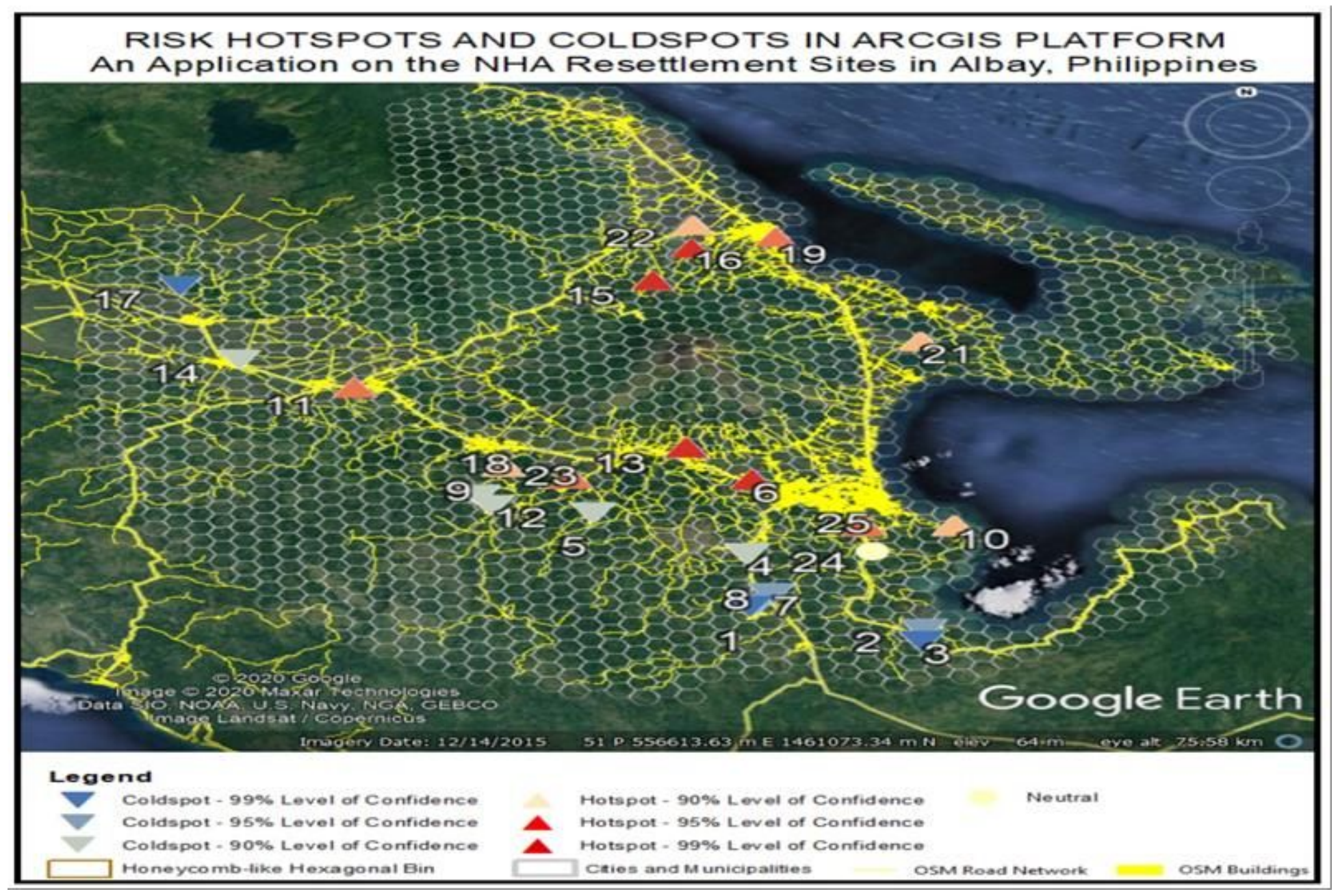

Figure 12

Risk Reality in NHA Resettlement Sites in Albay, Philippines 